\title{
LEGISLACIÓN Y JUSTICIA CONTRA BLASFEMOS. (CATALUÑA, SIGLOS XV-XVII)*
}

\author{
POR \\ MARTí GelaberTó VILAGRÁN \\ Investigador contratado \\ UFR des Sciences du Langage, de l'Homme et de la Société \\ Faculté des Lettres et Sciences Sociales de Besançon
}

\section{RESUMEN}

La represión contra los pecados de la lengua es importante objeto de atención por parte de la legislación y los tribunales de justicia en Europa desde la Baja Edad Media. En España se promulgaron severas leyes civiles y religiosas contra el delito de blasfemia con una desigual aplicación. En Cataluña los jueces laicos y eclesiásticos participaron de la política represiva privilegiando los resortes disuasorios de la coacción moral sin apenas recurrir a la coerción física.

PALABRAS ClAVES: Blasfemia, Religiosidad, Cataluña,

\section{LAW AND JUSTICE AGAINTS BLASPHEMOUS (CATALONIA, XV-XVII CENTURIES)}

\begin{abstract}
The repression against the sins of the language is a subject of intense attention from the law and courts of justice in Europe from the low Middle Ages. In Spain there were enacted severe civil and religious laws against the crime of
\end{abstract}

\footnotetext{
* Este trabajo es fruto de una investigación más amplia beneficiaria de una beca postdoctoral financiada por la Secretaría de Estado de Universidades e Investigación del Ministerio de Educación y Ciencia (EX2004-0257), realizada en la École des Hautes Études en Sciences Sociales de París (EHESS), Centre de Recherches Historiques, Groupe d'Études Hispaniques, dirigida por el profesor Bernard Vincent.
} 


\begin{abstract}
blasphemy by an unequal application. In Catalonia the secular and ecclesiastical judges participated in the repressive politics favoring deterrence springs of moral coercion wit little recourse to physical coercion
\end{abstract}

KEY WORDS: Blasphemy, Religiosity, Catalonia

Recibido/Received 08-02-2011

Aceptado/Accepted 01-04-2012

\title{
LA BLASFEMIA: UN DELITO EN LA ENCRUCIJADA JURÍDICA
}

Los conflictos de jurisdicción entre la justicia religiosa y la civil a la hora de procesar blasfemos era causa de encendidas discusiones teológicas y jurídicas en la España de los siglos XV-XVII. Frecuentemente los distintos tribunales con competencia legal sobre el delito de blasfemia se arrogaban la capacidad legítima para juzgar todo tipo de expresiones blasfematorias no importara cual fuera su naturaleza. Por esta razón, a menudo las justicias episcopal, inquisitorial y civil entraban en abierta pugna acerca de sus respectivas atribuciones como sucedía en otras tipologías delictivas como la brujería o la sodomía. Una polémica que se prolongará a través de los siglos y motivo de importantes controversias entre juristas y teólogos, entre jueces civiles y jueces eclesiásticos.

Tanto la justicia espiritual como la temporal compartían el principio de que no hay delito de blasfemia sin exclamación oral. Según los textos jurídicos canónicos y civiles no existe palabra blasfema si no se pronuncia en voz alta, no hay blasfemias «in mente». ${ }^{1}$ A partir de aquí las interpretaciones jurídicas de ambas justicias divergen sensiblemente. En líneas generales, en el continente europeo hay una diferencia sustancial respecto a la posición del poder espiritual y del poder temporal frente al pecado de la blasfemia. El primero es partidario de excluir temporalmente al blasfemo de la comunidad de cristianos, a la que será reintegrado después de habérsele aplicado las penas correctivas pertinentes para reconciliar al blasfemador con la sociedad que ha ofendido por su lenguaje sacrílego. El segundo también lo excluye, pero con marcas impresas en el cuerpo, señales imborrables de vergüenza del ultrajante delito.

Las justicias diocesana e inquisitorial se regían por las instrucciones transcritas en los cánones eclesiásticos. El Derecho canónico escriturado en las decretales $^{2}$ establece una triple división de las blasfemias ajustada a las

\footnotetext{
${ }^{1}$ Esta definición legal de blasfemia discrepa de la interpretación elaborada por el teólogo francés Jean Benedicti en 1601 cuando afirma que «si on y pensé seulement de coeur, sans rien dire de bouche, c'est blasphème mental». (Benedicti, J. 1601. La Somme des péchés et le remède d'iceux: 338, París).

${ }^{2}$ Leyes eclesiásticas que constituyen el cuerpo básico del derecho canónico reunidas por San Raimundo de Peñafort entre 1230-1234 por orden del Pontífice Gregorio IX.
} 
proposiciones teológicas de la doctrina escolástica: blasfemia herética, determina una declaración contraria a la fe cristiana; blasfemia imprecativa, implica una simple maldición opuesta al dogma cristiano; blasfemia contumeliosa, designa un desprecio o una iniquidad dirigida a Dios y al panteón celestial. La ley canónica establecía una distinción entre el blasfemo que profería injurias llevado por un sentimiento irrefrenable de furia pasajera, inconsciente del alcance real de sus palabras, de la del blasfemador reflexivo con intención expresa de atacar los dogmas o artículos de fe cristianos. La blasfemia era considerada, en todas las circunstancias, un pecado de infidelidad (infidelitas) contra la religión revelada con el agravante potencial de sumar un delito de herejía cuando se pronuncian exclamaciones ofensivas que implican desprecio, desdén u opiniones especulativas sobre el Creador del mundo y de su Hijo, o manifestar comentarios despectivos de la figura de la madre de Cristo y de los santos.

En sentido estricto, la Inquisición aplicaba el principio de considerar como blasfemias únicamente las palabras de negación, maldición, injuria o afrenta proferidas contra Dios o la Virgen, mientras que los insultos dirigidos a los santos sólo lo eran extensivamente. ${ }^{3}$ El último punto abre una puerta de debate entre los inquisidores sobre la interpretación jurídica y teológica que debía aplicarse a esta clase de blasfemias. ${ }^{4}$ El Derecho secular no tuvo ocasión de entretenerse en la polémica al establecerse bien claro en Las Partidas que son blasfemos todos aquellos «que con saña cuydan denostar a Dios e a sus santos». ${ }^{5}$ Esta ley general enciende la mecha del enfrentamiento jurídico con la Inquisición.

Las jurisdicciones inquisitorial y civil pronto entraron en conflicto abierto sobre quién era competente y quién dejaba de serlo para procesar delitos relacionados con la blasfemia. La Inquisición medieval y moderna basará su ordenamiento judicial sobre la doctrina de las circunstancias establecida por Santo Tomás y definida por el carácter herético o no de la blasfemia pronunciada. La teología escolástica señala que las blasfemias eran sospechosas de herejía cuan-

\footnotetext{
${ }^{3}$ Gacto, E. 1987. «Un caso de Inquisición. Los carnavales de Tubaria de 1640», en Homenaje al profesor Juan Torres Fontes, Vol. I: 537, Universidad de Murcia.

${ }^{4}$ Los inquisidores Carena y Sousa, el primero del Santo Oficio romano, y el segundo de la Inquisición portuguesa, sostienen que la afrenta a los santos es verdadera blasfemia pues representan a Dios. Otro importante inquisidor italiano, Giovanni Alberghini, piensa que las ofensas a los santos son blasfemias aunque no heréticas. El teólogo leonés Fernando Castro Palo matiza la cuestión cuando dice que solamente es herejía si se blasfema de los santos más importantes, los mencionados en las Sagradas Escrituras, pues al negarlos se les priva de su aureola de Bienaventurados, lo que implica negar una verdad de fe. Por su parte, el clérigo mercedario Juan de Rojas opina que «los inquisidores pueden proceder contra los blasfemos cuando la blasfemia sabe manifiestamente a herejía, no sólo a Dios sino también a los santos, que son parte del mismo cuerpo» (Gacto, E. 1987: 532).

5 Ibídem: 532.
} 
do fueran proferidas en determinadas situaciones que justificasen la gravedad de la acusación. Sobre este argumento teológico, el Directorium Inquisitorum de Nicolás Eymerich, en el siglo XIV, distingue dos clases de blasfemias: la blasfemia simple, expresión injuriosa o de ingratitud a Dios, la Virgen o los santos pronunciada en un acceso de cólera; y la blasfemia herética, palabras maliciosas proferidas conscientemente contra los artículos de fe cristianos con ánimo declarado de injuriarlos. Las primeras no estaban sujetas a la jurisdicción inquisitorial, las segundas, por el contrario, tenían que ser juzgadas como herejías y los culpables sufrir un castigo proporcionado al delito probado. ${ }^{6}$

Cuando el nuevo aparato de la Inquisición moderna creado por los Reyes Católicos en 1478 en aplicación de la bula concedida por el pontífice Sixto IV se puso en marcha, empezaron las pugnas de competencias sobre qué clases de tribunales eran aptos para juzgar a los blasfemos. Los tribunales civiles sostenían que el Santo Oficio tenía que limitar su capacidad jurídica a los acusados de herejía formal, ya que la blasfemia simple podía ser juzgada tanto por el derecho eclesiástico (en los tribunales diocesanos) como por el secular por considerársela una blasfemia de fuero mixto. Sin embargo, en el terreno práctico, nunca hubo una separación precisa entre blasfemias simples y blasfemias heréticas. Interpretar el sentido herético de una blasfemia resultaba complejo y nada fácil dadas las múltiples situaciones concretas en las que se hubiere exclamado. ${ }^{7} \mathrm{De}$ hecho, los tribunales inquisitoriales tendían a declararse competentes para juzgar a todos los blasfemos ante el riesgo de que la blasfemia más nimia escondiese un fondo herético, ${ }^{8}$ a pesar de las reiteradas instrucciones enviadas por la Suprema. ${ }^{9}$

Este monopolio inquisitorial frente al delito de blasfemia llevó a la autoridad real a amonestar a los inquisidores del reino por su excesivo celo en incoar

\footnotetext{
${ }^{6}$ Eymerich, N. 1982. Manual de Inquisidores: 101, Barcelona.

${ }^{7}$ Acerca de este particular, Julio Caro Baroja dice que un teólogo del siglo XVI dividía las blasfemias y proposiciones en varias clases según su importancia: heréticas, erróneas, temerarias y escandalosas. Cualquier expresión podía ser merecedora de ser incluida en algunas de estas categorías, dependiendo ello exclusivamente de la intención que tuviera la persona denunciante y del juicio que emitiera el inquisidor de turno (Caro Baroja, J. 1986. El Señor inquisidor y otras vidas por oficio: 25, Madrid).

${ }^{8}$ Esta precaución extrema la expresa muy bien el inquisidor italiano Carena, partidario de un mayor rigor judicial ante las blasfemias habituales: galeras durante tres años para los reos de baja condición social, y una fuerte pena pecuniaria si el condenado es de rango honorable.

${ }^{9}$ La legislación interna de la Suprema de los años 1537 y 1547 dictamina que toda una serie de expresiones normalmente proferidas en acaloramientos de cólera o de frustración como «por vida de Dios», «reniego de Dios», «a pesar de Dios», y otras exclamaciones irreflexivas estuvieran al margen de su jurisdicción, trasladándolas al ámbito competencial de los tribunales episcopales (García Cárcel, R y Moreno Martínez, D. 2000. Inquisición. Historia crítica: 25, Barcelona).
} 
sumarios procesales por simples blasfemias causadas por la ira pasajera, acto que no constituía herejía. Los monarcas determinaron la obligación de consultar al Inquisidor General antes de pasar al plano del requerimiento procesal. En las capitulaciones de Sevilla del año 1500, las máximas autoridades inquisitoriales del reino reunidas en aquella ciudad andaluza elaboraron las instrucciones por las que debían guiarse los jueces del Santo Oficio en su trabajo cotidiano de persecución de la herejía. En lo que respecta a los blasfemos, las normas eran que los calificadores de la Inquisición actuaran con la máxima cautela y prudencia antes de dictaminar si el blasfemo era merecedor de ser inculpado como hereje:

«Por quanto los inquisidores algunas veces proceden por cosas livianas non continentes herexia derechamente y por eso las palabras que más son las blasfemias que herejías, o dichas con enojo o yra, que de aquí en adelante no se prenda ninguno desta calidad, e si duda uviere que lo consulten con los inquisidores generales». ${ }^{10}$

Estas advertencias no fueron tomadas en consideración por los tribunales inquisitoriales. En Aragón, al menos, la actitud de los inquisidores provomió las quejas de las Cortes celebradas en Monzón en 1510, puesto que desde 1486 el tribunal de Zaragoza ya empieza a procesar a toda clase de blasfemos. ${ }^{11}$ Esta posición de resistencia inquisitorial provomió la promulgación de una Concordia dos años más tarde por la que se acordaba que la Inquisición sólo procesaría a blasfemos manifiestamente heréticos, orden transmitida por el inquisidor general Manrique en 1514 a todos los tribunales de distrito de España, y sancionada por el Papa León X en 1516 en la bula «Pastorales Oficii». ${ }^{12}$ Esta disposición parece que fue escasamente cumplida puesto que la Cortes de Aragón de 1530 vuelven a protestar por las mismas injerencias de carácter judicial.

En Castilla también se alzaron voces de protesta sobre el mismo asunto en los años 1515, 1524 y 1534, cuando las Cortes solicitaron reiteradamente que las causas por blasfemias fueran competencia única de los tribunales seglares, especialmente si el acusado pertenecía a la nobleza para evitar que su honor fuera mancillado por la intervención del Santo Oficio, ${ }^{13}$ ya que los inquisidores

${ }^{10}$ Lea, H. 1983. Historia de la Inquisición española, Vol. III: 742, Madrid.

11 Monter, W. 1992. La otra Inquisición: 42, Barcelona.

12 Santana Molina, M. 2004. El delito de blasfemia en el tribunal inquisitorial de Cuenca: 48, Universidad de Alicante.

${ }^{13}$ Cortes de Madrid de 1534, petición 26: «Otrosi, suplicamos a Vuestra Magestad que los blasfemos se castiguen con todo rigor, y si necessario fuere, se acreciente la pena, y porque acaece que con ira y pasión en juegos y cuestiones, y en otros enojos y porfía la gente noble y limpia, dize algunas blasfemias, y los inquisidores conocen della; y como todos no pueden saber la causa de la prisión; quedó infamado el tal noble y su linaje, y viene a pagar la blasfemia el que no la dixo, suplicamos a Vues- 
continuaban encarcelando rutinariamente a católicos ortodoxos por proferir palabras blasfemas en momentos de exaltación o desánimo. La solución de compromiso de atribuir a la Inquisición la tarea de enjuiciar a los blasfemos heréticos, y a la justicia episcopal y civil las blasfemias simples no arregló el tema. ${ }^{14}$

$\mathrm{Al}$ igual que en Castilla y Aragón, los conflictos de jurisdicción entre los tribunales civiles y la Inquisición eran moneda corriente en Cataluña. En Lérida, las autoridades seculares mantenían un control judicial absoluto en materia de procesamiento por delitos de blasfemia. En todos los procesos contra blasfemos en los que se insultaba a Dios o a la Virgen era al brazo secular a quien correspondía juzgar y dictar sentencia. No se recurría al tribunal inquisitorial para que se pronunciara acerca del eventual carácter herético de la blasfemia acusatoria. Las presiones de los inquisidores para tratar de imponer sus criterios sobre los jueces laicos eran rechazadas en virtud de las atribuciones otorgadas por el derecho consuetudinario contenido en las ordenanzas legislativas de la ciudad. En 1483, el inquisidor Juan Orts presentó a los máximos representantes políticos ilerdenses una propuesta por la que el Santo Oficio se haría responsable de procesar a los disidentes en la fe católica, entre los que se incluía a blasfemos, supersticiosos, fornicarios y demás pecadores públicos. El poder político local rechazó la propuesta justificándolo por ser contrario al respeto de las normas de la tradición jurídica de la ciudad. ${ }^{15}$

Las Cortes de 1532 solicitaron que los blasfemos fueran juzgados por los tribunales ordinarios, como tradicionalmente se había llevado a cabo, excepto en los casos de manifiesta herejía («sapiunt manifestam heresim»), ${ }^{16}$ y parece que así fue, ya que hasta mediados del siglo XVI no se registran procesos por blasfemia en el tribunal de Barcelona..$^{17}$ En ese mismo año tuvo lugar, precisamente, el más grave enfrentamiento jurisdiccional entre la Inquisición y las ins-

\footnotetext{
tra Magestad se provea como en tales casos la justicia seglar la castigue por todo rigor, y no otros juezes algunos. A esto vos correspondemos que mandamos que los nuestros justicias ejecuten lo que en esto disponen las leyes de nuestros reinos; y en lo que toca a los Inquisidores, no conocerán sino de los casos que de derecho pueden y deven conocer». (Sobre esta cuestión ver el artículo de Alonso-Guillaume, A. 1989. «Justice royale et oligarchies urbaines en Castille à travers les pétitions de Cortes (15181538), Mélanges de la Casa de Velázquez 25: 103-120).

${ }^{14}$ Jean-Pierre Dedieu en su trabajo sobre la actividad inquisitorial del tribunal de Toledo señala que durante la primera mitad del siglo XVI, el Santo Oficio de Castilla juzga todos los casos de blasfemia sin importarle un ápice los límites legales impuestos (Dedieu, J-P. 1989. L'Administration de la foi. L'Inquisition de Tolède, XVIe-XVIIIe siècle, Madrid).

${ }^{15}$ Gómez, M.P. 1992. «La ciutat de Lleida contra blasfems, heretges i bruixes», en Miscel.lanea. Homenatge a Josep Lladonosa: 382, Lleida.

${ }_{16}$ Bada, J. 1970. Situació religiosa a Barcelona: 92, Barcelona.

${ }_{17}$ Blázquez Miguel, J. 1990. La Inquisición en Cataluña. El tribunal del Santo Oficio de Barcelona, 1487-1820: 231, Toledo.
} 
tituciones catalanas a causa del estatuto jurídico de la blasfemia, tradicionalmente competencia de los tribunales laicos. En aquel año, Fernando de Loaces, fiscal inquisidor de Barcelona entre 1527 y 1542, encarcela a un grupo de ciudadanos acusándolos de blasfemar. Las autoridades del Principado,-consellers,${ }^{18}$ diputats,${ }^{19}$ obispos-, reaccionaron con presteza. Un comisión formada por nueve miembros, tres maestros en teología y seis doctores en cánones y leyes, determinaron la detención contraria al derecho de las instituciones catalanas. El brazo político y eclesiástico catalán apeló a la Suprema. A fines de septiembre, Loaces recibió la orden de sobreseer el procedimiento judicial iniciado porque no estaba clara si la naturaleza del delito que se les imputaba entraba en el ámbito jurídico inquisitorial. En el origen del apresamiento parece estar la venganza personal de Loaces en respuesta a un incidente ocurrido en el mes de julio de ese mismo año que comprometía la honorabilidad del alto funcionario del Santo Oficio. No se posee información sobre los nombres de los supuestos blasfemos ni cuál era su estatus social, aunque todo indica que serían de posición elevada. La jerarquía civil y religiosa del Principado difícilmente se hubiera comprometido tanto políticamente si los implicados hubiesen pertenecido a las clases humildes y no tuvieran honra que defender. ${ }^{20}$

El caso levantó de nuevo la sempiterna cuestión de las competencias judiciales. En las Cortes de 1533, los consellers de Barcelona presentaron un documento en que se pedía una mayor clarificación jurídica sobre qué instancias procesales eran las pertinentes para juzgar los delitos de blasfemia. En febrero de 1534, el inquisidor Calvet fue comisionado para fijar los criterios de actuación judicial en los procesos a blasfemos. Se estableció que antes de abrir cualquier diligencia procesal debería ser votada antes por cuatro consultores de la Real Audiencia y dos teólogos. ${ }^{21}$

\section{LA JUSTICIA CIVIL FRENTE AL DELITO DE BLASFEMIA: ¿UNA REPRESIÓN POLÍTICA?}

La teoría del derecho divino justifica la represión política de los blasfemadores con el pretexto de eliminar de la vida social un elemento perturbador del orden político y la paz religiosa. El monarca es responsable del bienestar moral

\footnotetext{
${ }^{18}$ En Barcelona eran los concejales ejecutivos de la ciudad elegidos anualmente. Su presidente recibía el título de Conseller en Cap.

${ }^{19}$ Los miembros de la Diputació, órgano supremo representativo de Cataluña, también conocida como Generalitat.

${ }^{20} \mathrm{El}$ episodio está muy bien descrito en la tesis doctoral de Moreno Martínez, D. 2002. Representación y realidad de la Inquisición. El conflicto de 1568: 370-376 (Tesis doctoral), Universitat Autonoma de Barcelona.

${ }^{21}$ Ibídem, p. 376.
} 
de su pueblo y del estricto respeto a los valores esenciales cristianos, así como el mantener la concordia interreligiosa y política en sus dominios. La preocupación primordial de la política legislativa de la monarquía es combatir las actitudes hostiles a la religión. El rey ha recibido la unción sagrada de la Iglesia -el poder le es otorgado por «la gracia de Dios»- y está obligado a defenderla de los enemigos del Ser Supremo, de hacer reinar la justicia y la misericordia en su reino. Como primer guardián en la defensa religiosa de su jurisdicción territorial es el encargado de reprimir los excesos verbales transgresores contra la providencia divina y neutralizar, de esta manera, los temibles arrebatos de la cólera celestial ante un hipotético relajamiento de la actividad represora de la autoridad laica. La severidad de la legislación real demostraría la voluntad expresa del soberano de evitar la aflicción del reino. Por este motivo, muchas de las leyes destinadas a combatir las blasfemias son dictadas, generalmente, a remolque de catástrofes naturales o políticas, interpretadas por la Iglesia y el Estado como actos de venganza divina a causa de la desidia de los poderes públicos en no querer exterminar la mala conducta de blasfemar. ${ }^{22}$

En todas las culturas de las distintas épocas históricas la blasfemia fue castigada con más o menos rigor por las autoridades civiles. El Código Justiniano, -conjunto de leyes auspiciadas por el emperador bizantino del mismo nombre elaboradas entre los años 534 y 565-, castigaba a los blasfemos con la tortura, y con pena de muerte si fuesen reincidentes. ${ }^{23}$ La ley visigoda aplicaba a los culpables de blasfemar el castigo de cien azotes, corte de cabellos y reclusión perpetua en la cárcel. De su parte, las leyes francas decretadas en la dieta de Aquisgrán (Alemania) en 818 consideraron la blasfemia como un pecado capital. Sin embargo, los historiadores consideran el punto de partida de la legislación civil medieval europea contra el delito de blasfemia a la iniciativa del monarca y futuro santo Luis IX de Francia (1226-1270), inspirador de una drástica serie de leyes que pretendían terminar con la costumbre de blasfemar, medidas legislativas promulgadas a su regreso de Tierra Santa en 1263. La justicia del rey francés aplicaba sin escrúpulos a los blasfemos contumaces la marca de la infamia con la señal del hierro candente grabada de por vida en la frente; en los casos extremos se les perforaba el labio o se les cortaba la lengua antes de ser conducidos al cadalso. Esta severidad fue elogiada por el Papa Clemente IV (1202-1268), quien no obstante aconsejaba suavizar las penas corporales. La ordenanza de 1347 relativa a los blasfemos publicada bajo el reinado de Felipe VI mandaba hender con un hierro ardiente el labio superior de los reincidentes para que se les vieran los dientes antes de ser liberados, señal imborrable de que

\footnotetext{
${ }^{22}$ Sobre esta cuestión ver la interesante monografía de Casagrande, C y Vecchio, V. 1999. Les péchés de la langue. Discipline et éthique de la parole dans la culture médiévale, París.

${ }^{23}$ Santana Molina, A. 2004: 41.
} 
se estaba en presencia de un blasfemo salvado por poco de la pena máxima. La legislación represiva medieval institucionalizada por Luis $\mathrm{X}$ fue renovada insistentemente desde finales del siglo XV y en el transcurso de la primera mitad del quinientos, en textos legislativos firmados sucesivamente por Carlos VII (1460), Carlos VIII (1490), Luis XIII (1510) y Francisco I (1524, 1525, 1544). ${ }^{24}$ En mayor o menor grado todas las administraciones de los países europeos adoptaron para sus respectivos ordenamientos jurídicos contra la blasfemia el patrón del modelo judicial galo. ${ }^{25}$

En lo que concierne a España la legislación civil se ocupó extensamente de la represión de los blasfemos desde los albores de la Edad Media. El Fuero Juzgo,-cuerpo de leyes que rigieron la vida legislativa del país hasta el derrumbe de la monarquía visigoda en 711-, impone a los blasfemos la infamia perpetua y la pérdida de bienes. En el Fuero Real, -legislación vigente en muchas partes del territorio peninsular, especialmente durante los siglos X y XI, en el período de colonización de las nuevas tierras conquistadas a los musulmanes cuando todavía no se habían creado los fueros municipales-, se dispone que el cristiano hallado culpable de blasfemia herética pague con su vida, y el judío que blasfemase reciba cien azotes y diez maravedíes de multa. Las Partidas,-código legislativo redactado bajo el reinado de Alfonso X El Sabio entre los años 1256 y 1265-, dedican el título XXVIII a legislar contra el pecado de blasfemar. Se disponía que todo caballero, rico-hombre y escudero que blasfemase de Cristo o de la Virgen María perdiese la propiedad de las tierras por un año, la primera vez; por dos años, la segunda vez; y para siempre, a la tercera vez. Al caballero y al escudero que no poseyeran tierra alguna se les desposeería la primera vez del caballo y de las armas. Si la blasfemia iba dirigida a un santo la pena se reduciría a la mitad. Por lo que respecta a la gente ordinaria propietaria de bienes encontrada culpable de proferir blasfemias se les desposeía de la cuarta parte de sus propiedades, la primera vez; en la segunda, se procedería a quitarles la tercera parte; y en la tercera, la mitad de su patrimonio con el riesgo aparejado de ser desterrados si persistían en el horrendo vicio. La gente común que no tenía ninguna o muy escasa riqueza con la que responder ante la justicia, recibía en compensación cincuenta latigazos la primera vez; a la segunda se les marcaba los labios con un hierro ardiente; y a la tercera se les cortaba la lengua. Cuando la blasfemia iba acompañada de un acto execrable como un crimen o un sacrilegio se imponía directamente el máximo castigo previsto, con la diferencia de que al campesino pobre o al desarraigado habitante de la plebe urbana se les

${ }^{24}$ Leveleux, C. 2001. La parole interdite, le blasphème dans la France médiévale (XIII ${ }^{e}$ XVI ${ }^{e}$ siècle): du péche au crime: 74, París.

25 Belmas, E. 1989. «La montée des blasphèmes du Moyen Âge au XVII siècle», en J. Delumeau (ed.), Injures et Blasphèmes: 13-33, París. 
amputaba la mano en lugar de la lengua. A los judíos y moros, las Partidas prescribían penas corporales y monetarias, cuyo montante quedaba a criterio del Rey, según la gravedad del contenido de la blasfemia.

Las disposiciones de las Partidas fueron confirmadas enteramente por el monarca Juan I en Briviesca (Burgos) en 1387. ${ }^{26}$ Enrique IV les añadió una ley promulgada en la ciudad de Toledo en 1462 donde se decía que los individuos culpables de blasfemar en la Corte o en cinco leguas alrededor recibirían cien azotes públicamente en el lugar más concurrido de la localidad con amputación de la lengua. Si el hecho tuviera lugar en otra parte del reino, en vez de aplicarle el centenar de latigazos, se le quitaría la mitad de sus bienes, sin posibilidad de indulto, recibiendo el acusador la mitad de todo lo embargado. ${ }^{27}$ En la primera mitad del siglo XV la legislación real portuguesa también promulgó leyes represivas contra los blasfemadores, Juan I de Portugal publica una ley contra blasfemos que «non temendo as grandes penas eternaes e temporaes que pollos comuns e noesas ley som postas» («No temen las grandes penas eternas y temporales que por lo común son puestas en las leyes»). ${ }^{28}$

Los Reyes Católicos enriquecieron el arsenal legislativo hispano agregando nuevas leyes dirigidas a erradicar las blasfemias. En una pragmática correspondiente a las Ordenanzas Reales de Castilla publicada en Madrigal de las Altas Torres (Ávila) en 1476, se otorga a cualquier persona que escuchara pronunciar una blasfemia la facultad de prender inmediatamente al responsable y conducirlo ante la justicia para que respondiese del delito. ${ }^{29}$ Los monarcas renovaron la vigencia de las anteriores leyes y añadieron otras que reforzaron su carácter represor. Por pragmática publicada en Valladolid en fecha de 22 de julio de 1492, se acuerda castigar con penas de un mes de prisión la primera vez a todo aquel que pronunciase frases ofensivas como: «Descreo de Dios y despecho de Dios, y mal grado haya Dios, ni ha poder en Dios, ni pese a Dios, ni lo diga Nuestra Señora la Virgen María su Madre»; la segunda vez el infractor conocería la pena de destierro durante seis meses y multas de mil maravedíes, distribuida en tres partes, una parte al acusador, otra para el juez, y la restante para los gastos alimenticios de los pobres de la cárcel; la tercera reincidencia supondría para el acusado la enclavación de la lengua. Este atroz castigo era sustituido por un año de exilio y dos mil maravedíes de multa si el blasfemo fuera escudero o persona de mayor condición social. ${ }^{30}$ La ordenanza hecha pública el 9 de junio de 1500

\footnotetext{
${ }^{26}$ Novísima Recopilación de las leyes de España, Madrid, 1829 (Libro XII, Título V, Ley I: 317).

${ }^{27}$ Ibídem (Libro XII, Título V, Ley II: 317).

${ }^{28}$ Baquero-Moreno, H. 1976. «Injurias e blasfemias proferidas pelo homen medieval portugués na sua vida de relaçao social», en Tensoes sociais em Portugal na idade media: 85, Oporto.

${ }^{29}$ Novisima Recopilación (Libro XII, Título V, Ley III: 317-318).

${ }^{30}$ Ibídem (Libro XII, Título V, Ley IV: 318).
} 
suprime esta discriminación al proclamar que las leyes contra blasfemos se aplicaran sin excepción a toda clase de personas sin establecerse diferencias en cuanto a las categorías sociales, bajo amenaza de padecer el juez incumplidor la misma pena que el blasfemo. ${ }^{31}$

En 1525, en tiempos del reinado de Carlos y Juana de Castilla, una pragmática hecha pública en Toledo confirmó las disposiciones legislativas tomadas unos años antes por Isabel y Fernando, reafirmando las penas prescritas para quienes dijesen palabras injuriosas contra Dios y su corte celeste:

«Por quanto Nos fue hecha relación, que muchas personas, así hombres como mugeres, tienen costumbre de jurar por vida de Dios, y no creo en la fe de Dios, y no ha poder en Dios, y debido a Dios, y otros juramentos malos y feos en desacatamiento de nuestro Señor Dios».32

Felipe II adjuntó a las penas previstas en la antigua ordenación jurídica la de diez años de galeras para los blasfemos convictos de renegar contra el Creador y de seis para los demás juramentos que mereciesen el horadamiento de la lengua. ${ }^{33}$ Muy probablemente estas nuevas disposiciones legales vendrían determinadas por la imperiosa necesidad de la monarquía del Rey Católico de proveerse de recursos humanos para afrontar las crecientes necesidades de las campañas militares navales que se desarrollaban en el Mediterráneo y en el Atlántico. ${ }^{34}$

En 1639, Felipe IV estableció una pena de diez días de presidio y veinte mil maravedíes de multa para el culpable de blasfemia, la primera vez; de treinta días de cárcel y cuarenta mil maravedíes de sanción monetaria con cuatro años de destierro, para la segunda vez; sustituyéndose por prisión o galeras según la calidad del delincuente. Si el condenado fuera insolvente se conmutaría dicha pena por otra, a criterio del juez, sentencia proporcionada a la gravedad de la blasfemia, comunicando el magistrado su resolución judicial a la Chancillería,

\footnotetext{
${ }^{31}$ Ibídem (Libro XII, Título V, Ley V: 318).

32 Ibídem (Libro XII, Título V, Ley VI: 318).

En aquel mismo año de 1525 Don Beltrán de Guevara, -noble caballero de ilustre familia pero de escasos recursos y padre del célebre Antonio Beltrán de Guevara-, dirige un memorial al emperador donde expresa de manera personal los vicios que a su juicio envenenan a la sociedad española de la época. Entre las muchas demandas reivindica un saneamiento moral de la espiritualidad española, que obre siempre con devoción y especialmente quite «las grandes blasfemias que en sus reinos se dizen contra Dios» como lo hizo su abuela, la reina Isabel I (Redondo, A. 2007. Revisitando las culturas del Siglo de Oro. Mentalidades, tradiciones culturales, creaciones paraliterarias y literarias: 41. Acta Salmanticensia, Estudios filológicos, 314, Universidad de Salamanca).

${ }^{33}$ Novísima Recopilación (Libro XII, Título V, Ley VII y VIII: 318-319).

${ }^{34}$ Dedieu, J-P. 1985. «El modelo religioso: las disciplinas del lenguaje y de la acció», en B. Bennassar (ed.), La Inquisición española: 214, Barcelona.
} 
Audiencia y Sala de Alcaldía para que pudiese ejecutarse. La nueva pragmática añade la novedad de que para acceder al desempeño de cualquier cargo en la administración del Estado o en los municipios se requería información previa acerca de si el solicitante hubiese incurrido en delito de blasfemia, en caso afirmativo el aspirante quedaba excluido automáticamente en su pretensión de conseguir un empleo en la función pública. ${ }^{35}$ Estas disposiciones volvieron a renovarse en 1655 y 1656, Carlos II, en 1666 y 1670, renovó todas las medidas legislativas aprobadas por su predecesor en el trono. ${ }^{36}$ En la siguiente década del siglo XVII el gobierno de Don Juan José de Austria promulgó dos decretos dirigidos a reprimir a los blasfemos. El 28 de diciembre de 1677, salió la orden de proceder contra la «relajación de costumbres de los vagamundos, juradores, y blasfemos» ${ }^{37}$ Unos meses más tarde, el 22 de abril de 1678, una nueva ley prohibía el «frecuente abuso que ay en los juramentos y blasfemias», con aplicación de castigos sin distinguir el rango de las personas. ${ }^{38}$

Las leyes contra los blasfemadores insisten sobre el aspecto del orden público. La ejemplaridad de las penas busca disuadir a potenciales imitadores y, simultáneamente, aterrorizar las conciencias de las gentes que podrían pecar por laxitud u olvido. Las ordenanzas judiciales contienen una llamada explícita a la delación, el delator percibe una parte sustanciosa de la multa a desembolsar por el blasfemo, y no denunciar implica un riesgo de persecución judicial.

De lo expuesto hasta aquí se desprende que en España el período más activo en materia legislativa contra la blasfemia tuvo lugar en el transcurso de la primera mitad del siglo XVI, en los edictos de los años 1492, 1500, 1525 y 1566. Alain Cabantous indica que las disposiciones reales dirigidas contra los pecados de la lengua en Europa se insertan dentro de una estrategia global de actuación cuyo objetivo era consolidar la autoridad de unas monarquías absolutas todavía débiles en el plano político. En España, las principales leyes contra los blasfemos son legisladas no tanto para reafirmar el potencial autoritario del Estado Absoluto como para resolver situaciones que requiriesen soluciones políticas en coyunturas especialmente delicadas para la religión católica. ${ }^{39}$ En este sentido, las pragmáticas publicadas durante el quinientos se enmarcan en la defensa y afirmación del peso del catolicismo frente a las poblaciones conversas de judíos y musulmanes (edicto de 1492), mudéjares (edictos de 1500 y 1525), y calvinistas sublevados de los Países Bajos (edicto de 1566). Un plan diseñado

\footnotetext{
${ }^{35}$ Novísima Recopilación (Libro XII, Título V, Ley X: 320).

${ }_{36}$ Ídem.

${ }^{37}$ Graf Von Kalmen. 2002. Juan José de Austria en la España de Carlos II. Historia de una regencia: 521, Lleida.

38 Ibídem: 522.

${ }^{39}$ Cabantous, A. 1998. Histoire du blasphème en Occident (XVI ${ }^{e}$-XIXe siècle): 61, Paris.
} 
estratégicamente para reforzar la unidad de la fe religiosa que aglutinara las diversas etnias y credos religiosos que hasta entonces habían convivido en la península, una unidad confesional garantía de la cohesión territorial que supliera la falta de centralización política en que se vertebraba el país configurado en las Coronas de Castilla y de Aragón.

Jesús María Usunáriz señala que los tribunales reales apenas tuvieron relevancia en la persecución de la blasfemia. Según los datos aportados, en el Archivo de la Chancillería de Valladolid existen 19 procesos contra blasfemos procedentes del País Vasco, de ellos, 17 fueron juzgados entre 1494 y 1523. En los fondos de Tribunales Reales del Archivo General de Navarra hay una docena de procedimientos judiciales por el mismo delito. ${ }^{40}$ Estas informaciones dan fundamento a la explicación de que en España nunca se persiguió a los blasfemos por motivos políticos, el Estado jamás consideró a los blasfemadores elementos peligrosos amenazadores de la cohesión social y religiosa de la nación, ${ }^{41}$ cosa que si ocurría en Francia enfrentada a las cruentas guerras de religión, y también en Inglaterra, tras el cisma de Enrique VIII con la Iglesia de Roma.

Las leyes reales más antiguas contra los blasfemos promulgadas en el marco de la Corona de Aragón se encuentran contenidas en las disposiciones jurídicas del siglo XIII. En el Fori Regni Valentiae publicado en tiempos del rey Jaime I (1208-1276) se castigaba a los blasfemos a pagar cien sueldos si «jurara en joch dient mal de Deu o de Sancta Maria» («Si jurase en el juego diciendo mal de Dios o de Santa María»). Por su parte, el monarca Alfonso II en las Cortes de Monzón de 1289 declaró lo siguiente: «Ordenam e statuim que algun home no diga mal de Deu, ni de Nostra Santa María...» («Ordenamos e instituimos que ningún hombre diga mal de Dios, ni de Nuestra Señora Santa María»). En general, las penas aplicadas consistían en tandas de azotes redimibles por multas. Así, los representantes de los diversos estamentos sociales reunidos en asamblea en aquella localidad aragonesa acordaron que el blasfemo sería castigado con diez latigazos o veinte sueldos de pena pecuniaria. Los castigos serán considerablemente agravados en las Cortes de 1363 celebradas en la misma localidad oscense en tiempos de Pedro III (1317-1387) con aplicación de la pena de muerte para la persona blasfema que hubiera pronunciado la ofensa sacrílega con ánimo deliberado de injuriar a la divina majestad, o en su defecto, enclavación de la lengua mediante un garfio para aquellos que la hubiesen proferido bajo un estado de alteración emocional causado por el juego o reyerta y no fue-

\footnotetext{
${ }^{40}$ Usunáriz, J.M. 2006. «Verbum Maledictionis». La blasfemia y el blasfemo de los siglos XVI y XVII» en R. García Bourrellier y J. M. Usunáriz (eds.), Aportaciones a la historia social del lenguaje: España, siglos XIV-XVIII: 210, Madrid.

41 Ibídem: 211.
} 
ran plenamente responsables mentales de su acción. En 1380, el mismo rey manda publicar otra ley calco de la anterior:

«Qui paraulas nefandisimas, Deu Omnipotent, e la Sua Virginitat tocants, e los Sants, e las Santas de Deu, dira, si ab propósito ho dira sens sperança de alguna venia, o perdo que muyra, si en joc, baralla, o en altra manera per ira, o per cas ho dira, portant per mitg de la lengua una verga de ferro sie scobat». ${ }^{42}$

Durante el reinado del monarca Alfonso el Magnánimo (1396-1458) se dictaron una serie de leyes dirigidas a prohibir las injurias y las palabras blasfemas con sus respectivas penas pecuniarias y corporales. Curiosamente, los castigos infligidos a las personas mal habladas son rebajados a excepción de aquellas que hubiesen pronunciado expresiones de desprecio o de blasfemia hacia Dios o la Virgen María. Si se juraba por algún miembro o parte física de un santo o de un hombre la pena se relajaba considerablemente. El culpable de insultar a una figura del calendario cristiano recibía tradicionalmente una sanción económica de diez a veinte sueldos o una punición corporal sustitutiva de diez latigazos. La nueva ley disponía que la multa fuera rebajada a un sueldo o un azote en caso de castigo físico. Ignoramos si la Real Audiencia de Barcelona ${ }^{43}$ aplicó con severidad las leyes promulgadas por la institución monárquica y si los magistrados tuvieron verdadero interés en procesar a blasfemos. Los procesos criminales juzgados por la más alta instancia judicial catalana se perdieron, y sólo se conservan las causas civiles.

Las leyes locales copiaron con una gran cantidad de variantes la base legislativa del ordenamiento real basada en la alternativa de azotes o multas. En la Cataluña de la Baja Edad Media los castigos corporales tenían lugar a plena luz del día en plazas y calles bien concurridas de gente. El condenado, a torso desnudo, era azotado por el verdugo y paseado después a lomos de un asno por los principales lugares de la población, llevando clavado un garfio en la lengua, si

\footnotetext{
42 «Que palabras nefandísimas, Dios Omnipotente, tocantes a su virginidad, y a los santos, y a las santas de Dios, dirá, si con propósito lo dirá sin esperanza de alguna venía, o perdón que muera, si en juego, pelea, o en otra manera por ira, lleve en medio de la lengua una verga de hierro» (Constitucions $y$ altres Drets de Catalunya, compilats en virtud del Capitol de Cort LXX-XII. de las Corts per la S.C.Y.R. majestad el Rey Don Philip IV, nostre senior celebradas en la ciutat de Barcelona any MDCCII, Generalitat de Catalunya, Barcelona, 1995, Libro 9, Título II, Constitución 10).

${ }^{43}$ Máximo órgano judicial en Cataluña, presidido por el virrey, representante del monarca en el Principado, institución reorganizada en 1493. A nivel territorial la justicia era administrada por el veguer, funcionario real a cargo de cada una de las diecisiete vegueries en las que estaba dividida Cataluña. Las sentencias de los veguers podían ser recurridas ante la Audiencia. El veguer tenía jurisdicción sobre los nobles y miembros del tercer estamento, pero no sobre los eclesiásticos y los militares (Acerca de la problemática jurisdiccional de la justicia inferior en Cataluña ver la obra de Lalinde Abadía, J. 1966. La jurisdicción real inferior en Cataluña (Corts, Veguer, Battles), Barcelona.
} 
la gravedad de la blasfemia le hubiera hecho merecedor de ello, signo de la infamia cometida contra Dios. El blasfemo era finalmente expuesto en la picota de la ciudad o del pueblo para sufrir la humillación y el escarnio público del vecindario. Comúnmente, los tribunales municipales catalanes daban a elegir al individuo convicto de blasfemia entre la opción de recibir las penas físicas prescritas en la ley, o bien redimir su delito por el pago de un estipendio monetario en beneficio de las arcas del municipio. En 1301, los blasfemos juzgados por las autoridades laicas de Barcelona recibían el castigo arriba mencionado, con horodamiento de lengua en los casos más graves, permaneciendo tres días inmovilizados en la picota, a no ser que el reo decidiera evitar tan infamante vergüenza desembolsando cien sueldos de multa. En 1362, las autoridades barcelonesas publicaron un bando donde se decía que el blasfemo encontrado culpable por la justicia podía librarse de la pérdida de la lengua mediante pago de la importante suma de mil sueldos destinada al erario público. Ciertamente, la inmensa mayoría de personas no estaban en disposición de afrontar el desembolso de tan elevado montante económico para intentar salvar el órgano del habla, y todos los castigos degradantes asociados, como lo demuestra el cruel castigo infligido en diciembre de 1390 a un desarraigado social de la urbe barcelonesa que había osado mentar injuriosamente el nombre de Cristo y de su madre:

«Fu sentenciat un hom, appellat en Moges, qui hauria dites alcunes deshonestes e leges paraules de Nostre Senyor Jeshu Crist e de la sua beneyta Mare, e fo, ab un fus o garfi ficat per mig la lenga, ab un ventre de vou ple de buyna, e ab cordes de canes escobat, per la ciutat, donantli ab los dits ventres per la cara, cap e persona sua. Puys, fo posat en lo costell, proa lo cantó del carbó, hon estech per espay de mitra hora e no plus». ${ }^{4}$

A principios del siglo XV la autoridad civil de Barcelona perfecciona el decreto contra blasfemos conservando la distinción social respecto a la aplicación de penas: castigos corporales y vergüenza pública para los ciudadanos de condición más humilde; y penas pecuniarias, o como mucho cárcel, para las clases pudientes. Si los blasfemadores fueran gente corriente, «homes de peu» («hombres de a pie»), pagarían una multa de cincuenta sueldos la primera vez, en caso de no poder pagar recibirían treinta azotes en la vía pública; en la segunda oca-

\footnotetext{
44 «Fue sentenciado un hombre, apellidado Moges, que había dicho algunas deshonestas y ligeras palabras de Nuestro Señor Jesucristo y de su bendita Madre, y fue, con un huso o garfio metido en medio de la lengua, con un vientre de buey lleno de boñigas (excrementos de ganado), y con cuerdas de cañas azotado por la ciudad, dándole con los dichos vientres por la cara, cabeza y toda su persona. Después, fue puesto en la picota, colocado en el lado del carbón, donde estuvo por espacio de media hora y no más» (García y García, A. 1995. «Los juramentos e imprecaciones en los «Usatges» de Barcelona», Glossae. Revista de historia del derecho europeo 7: 89-123).
} 
sión, se les azotaría en un recorrido por las principales calles de la ciudad; a la tercera, se les clavaría un garfio en la lengua; a la cuarta, sería nuevamente flagelado y puesto en la picota de la humillación durante toda una jornada. La gente rica solventaba la situación con pago de dinero o días de cárcel, si reincidían con ayunos a pan y agua. ${ }^{45}$ La pena capital quedaba excluida en todos los casos. Legislaciones parecidas abundaban en la geografía catalana.

En las antiguas leyes del municipio pre-pirenaico de La Pobla de Lillet, -localidad situada en el extremo norte de la provincia de Barcelona, perteneciente a la diócesis de Solsona-, correspondientes al año 1355, se condenaba al blasfemo que hubiera injuriado el nombre de Dios o de su santa progenitora a serle amputada la lengua. Si la blasfemia fuera dicha por un niño menor de catorce años se le recluiría un día entero en el castillo de la baronía de los señores de Pinós, casa nobiliaria bajo cuya jurisdicción se encontraba el municipio. Esta ley tan extremadamente dura fue suavizándose con el tiempo, de modo que en 1375 el entonces señor feudal del territorio, Bernat Galcerán de Pinós, se reservaba a su arbitrio la aplicación de las penas corporales y monetarias para castigar a los blasfemos:

«Encara, que com crexent maleficio crecer deia pena, e molt malamente alcuns juren per la manera damont dita de nostre senior Deus e de la Verge Maria e de sos sants e Santes, vol e mana lo dit senior que de aitals coses cascun s'abstengan, en altra manera sapiens sera punit corporalmente per lo dit senior a arbitre e conexença sua, segons que l'inhonest jurar voldrà e requerrà». 46

El 25 de octubre de 1393, otra ordenación contra blasfemos publicada en la vecina población de Baga descarta aplicar castigos físicos, y el correctivo se limita sólo al plano de las sanciones económicas. El blasfemo entregaría la mitad del importe de la multa al señor del lugar, y el resto al acusador. La disposición viene preceptuada esta vez por los máximos representantes del poder civil de la localidad, novedad significativa respecto a los edictos promulgados anteriormente. El bando también pormenoriza la tipología de insultos y su pena correspondiente: si se juraba por la cabeza o el cuerpo de Dios o de la Virgen María, el blasfemo pagaría su ofensa en forma de vino y dinero; quien jurase por el hí-

\footnotetext{
45 Vinyoles, M.T. 1990. «La violencia marginal a les ciutats medievals (exemples dels volts del 1400), Revista d'història medieval, I: 160.

46 «Aún, que como maleficio creciente como la pena, y muy malamente algunos juran por la manera de Nuestro Señor Dios y de la Virgen María y de sus santos y santas, quiere y manda dicho Señor que de tales cosas cada uno se abstenga, y en otra manera sepan que serán castigados corporalmente por el dicho Señor a arbitrio y conocimiento suyo, según que el deshonesto jurar requiera» (Serra Vilaró, J. 1936. «Ordinacions contra la blasfemia i el joc. Un capitol d'història pirenanca», Analecta Sacra Tarraconensia XII: 415).
} 
gado, culo, vientre o tripas de Nuestro Señor recibiría la misma pena en especies y en moneda; el que pronunciase frases despreciativas de claro tono retador hacia la divina providencia como «a despeig de Deu se farà ho que Deu no ha de poder» («A despecho de Dios se hará lo que Dios no ha de poder») o «ho que malgrat n'aia Deu» («Pese a que no haya Dios»), sería penado con doce dineros de multa por cada vez que repitiera la exclamación injuriosa. Si las blasfemias fueran dirigidas a los santos y contuvieran referencias a los órganos corporales, el infractor pagaría dos dineros, la mitad si no las hubiere. ${ }^{47}$ En 1422, el señor de aquellas tierras ordenó que el alcalde de Baga nombrase ocho hombres de probada moralidad con la función específica de denunciar a toda persona que oyeren blasfemar, otorgándoseles la capacidad de ejecutar a su propia iniciativa las penas dispuestas en el ordenamiento jurídico local. ${ }^{48}$

Durante todo el siglo XV se promulgaron en Cataluña leyes civiles parecidas. En las Ordinacions del Consejo Municipal de Manresa de 1439 se acordó aplicar una serie de disposiciones legislativas contra el hábito de jurar: quien jurase en el nombre de Dios, de su Santa Madre, de los miembros de Cristo y de la hostia consagrada, pagaría ocho ducados de multa; la persona que blasfemase de las partes genitales de Jesucristo y la Virgen María, o jurase «mala part hi hará Deu o la Verge Maria» («Mala parte hará Dios o la Virgen María») o por las «plagues» («plagas»), quince ducados de sanción; el renegador que blasfemara diciendo «malgrat o en despit o Deu no ha poder o que Deu no volgué o la Verge Maria» («Pese o a despecho o Dios no ha de poder o que Dios no quiere o la Virgen María»), diez sueldos en concepto de remisión monetaria u ocho días de prisión como pena sustitutoria; los juramentos dirigidos a los miembros de los santos tendrían cuatro ducados de multa, y tres por blasfemar simplemente de ellos.

En el siglo XV la justicia laica da la impresión de ser muy laxa con los convictos por blasfemia. De los setecientos procesos criminales juzgados por la jurisdicción civil de la ciudad de Lérida, sólo ocho procedimientos judiciales fallados entre 1402 y 1456 tienen relación con los blasfemos. Después de este año solamente se contabiliza otro caso, en 1485 , en el intervalo no hay registrada ninguna otra causa, bien porque no se llegó a instruir o porque se perdió. Ningún convicto recibió la pena capital. El castigo más cruel le fue aplicado el 5 de enero de 1420 a Pedro Franch, oriundo de Valladolid, declarado culpable de blasfemar contra Dios y la Virgen mientras jugaba a las cartas al decir públicamente que la madre de Cristo era una prostituta: «Malgrat nagués la bagassa (puta) de la Verge Maria». Sin dilaciones se procedió a infringirle el castigo re-

\footnotetext{
47 Ibídem: 416.

48 Ídem.
} 
servado a los blasfemos de condición plebeya. Amordazado, ${ }^{49}$ desnudo de torso, mitra de la difamación colocada en la cabeza, el verdugo procede a azotarlo hasta la extenuación sin llegar a provocarle la muerte, después se le clava la lengua con un garfio antes de ser desterrado de la ciudad y de sus términos. Dos sentencias fueron más benevolentes, la primera pronunciada el 9 de junio de 1402 en la persona de Domingo Ferrandiç, natural de Zaragoza, culpable de renegar de la Virgen por haber perdido unas armas en un hostal, y la otra hecha pública el 9 de agosto de 1407 contra el portugués Rodrigo Vasqueç, por blasfemar en una partida de juego, recibieron cada uno cuatro azotes y sus cabezas y brazos fueron colocadas en el cepo «banquet» durante un día. Quien se libró de las penas corporales fue un labrador de nombre Pere Johan, alias Gros, vecino de Lérida, declarado blasfemo por sus jueces el 10 de enero de 1444 por ofender a Dios de palabra cuando discutía con otro campesino. Es condenado a una pena espiritual inspirada en los manuales inquisitoriales de la Edad Media, pero aplicada por el poder secular, consistente en conducir al reo en un día festivo a la iglesia de Sant Joan y a permanecer de pie en las escalinatas del templo el tiempo que durase la misa, ataviado con una camisa, cadena al cuello y cirio entre las manos, y a sus pies un cartón lleno de paja y cebada símbolo de su bestialidad..$^{50}$ Del resto de los encausados, uno fue absuelto por falta de pruebas inculpatorias, de los demás no conocemos las sentencias.

En los siglos XVI y XVII los veguers de Lérida continuaron procesando a blasfemos pero de una manera casi testimonial. Los casos juzgados se reducen a dos y las penas aplicadas son poco duras. Así, el 29 de octubre de 1512 se incoa proceso contra una persona oriunda de Castilla apodada El Alonso, acusada de blasfemia y de negar a Dios. Durante una partida de juego de pelota que tuvo lugar en el patio trasero de la iglesia de Sant Joan, el encartado dijo con gran enojo: «No creo en Dios, ni digo oración, porque ya no me puede ayudar Dios». Fue encadenado y expuesto al oprobio público en una de las principales calles de la ciudad.$^{51}$ El otro caso sucedió en 1667 durante una procesión religiosa en Solsona (población perteneciente a otra vegueria) pero esta vez la sentencia fue examinada por la Suprema. ${ }^{52}$

Los jueces demostraban más severidad con los ciudadanos que no eran de Lérida, pues los naturales de la ciudad ilerdense recibieron condenas benignas

\footnotetext{
${ }^{49}$ La mordaza consistía en la aplicación de un instrumento de tortura que mantenía la lengua fuera de la boca.

${ }^{50}$ Pese a que la pena se fundamenta en las leyes inquisitoriales, al reo no se le considera hereje ni se realiza ningún tipo de consulta a la Inquisición.

${ }^{51}$ Lladonosa Pujol, E. 1974, Historia de Lleida, Vol. II: 155, Tárrega.

${ }^{52}$ Romero García, E. 1984. «Procesos criminales en la Lérida de la segunda mitad del siglo XVII», en I Congrés d'Història Moderna de Catalunya, Vol I: 499, Universitat de Barcelona.
} 
o la absolución. El acusado tenía derecho legal a ciertas garantías procesales que lo amparaban de la indefensión jurídica si de verdad creía ser inocente y todos los testimonios se giraban en su contra. Si su economía lo permitía podía contratar los servicios de un abogado defensor que solicitase en su nombre una «cédula de deffensions», una especie de pliego de alegaciones contra el procedimiento penal en curso. A través de la pluma del letrado, el encausado eleva al tribunal su queja por la forma en que se tramita su proceso, recusando los testigos del fiscal por considerarlos enemigos personales y de haber interpuesto las denuncias únicamente con la finalidad de perjudicarle. Solicita presentar testimonios nuevos que invaliden las acusaciones y ser absuelto del delito. La duración de este tipo de recurso era largo, un promedio de diez meses. ${ }^{53}$

En el transcurso de los siglos XVI y XVII los obispos de Cataluña buscan la colaboración de las justicias locales para reprimir los excesos verbales de los blasfemadores escandalosos que pululaban por doquier en la geografía del Principado. La nobleza que ostentaba la jurisdicción señorial de muchos territorios de Cataluña colaboraba con el poder espiritual en su aferrada cruzada contra las blasfemias. En el siglo XVII los sucesivos titulares del dominio de la batllia ${ }^{54}$ de Castellar, -en la comarca del Vallés Oriental, provincia y diócesis de Barcelona, bajo la autoridad de la familia nobiliaria de los Clasqueri-, promulgan una seria de leyes destinadas a reprimir los excesos verbales de los blasfemos. Entre 1597 y 1650 se multaba con cinco sueldos a toda persona que jurase en nombre de Dios, de la Virgen María y de los santos. Además, se instaba al blasfemo a que hiciese una cruz con dos cañas y la besase con aflicción de arrepentimiento. Esta ordenación iba acompañada de la prohibición de decir palabras injuriosas con pago de tres sueldos y treinta días de prisión para el infractor. ${ }^{55}$

En el siglo XVI, algunos municipios catalanes destinan repartir las penas pecuniarias recaudadas al cincuenta por ciento entre la Corte del señor del lugar y la obra de culto de la iglesia parroquial. A este respecto, en 1563, el barón de Pinós, Don Luis de Beaumunt, que ostentaba, además, los títulos nobiliarios de Condestable de Navarra y Conde de Lerín, notifica por edicto a los habitantes de La Pobla de Lillet que toda persona hallada culpable de atentar por reniegos y blasfemias al honor de Dios, la Virgen María y los santos del paraíso sería multada con cinco sueldos a distribuir entre la jerarquía nobiliaria y el rector de la parroquia. Diez años más tarde, la autoridad local decidió multar con un suel-

\footnotetext{
${ }^{53}$ Las informaciones reseñadas aquí son extraídas del artículo de Gómez M.P. 1992: 378-379.

${ }^{54}$ Batllia: Territorio que dependía del Batlle, funcionario jefe a nivel de ciudad o de pueblo, nombrado por cualquier instancia (el rey, el señor, el obispo) para que controlase la jurisdicción. Solía estar sometido a la autoridad del veguer (Kamen, H. 1998. Cambio cultural en la sociedad del Siglo de Oro. Cataluña y Castilla, siglos XVI-XVII: 435, Madrid).

55 Perich Vidal, G. 1989. La Cort del Batlle de Castellar, Castellar del Vallés.
} 
do aplicado a los gastos de compra de cirios y velas destinados a la iluminación del templo parroquial a quien jurase de Cristo y de su madre, cantidad que se rebajaba a seis dineros si los insultos iban dirigidos hacia algún santo o santa. ${ }^{56}$ Sin embargo, esta relativa tolerancia de los tribunales laicos frente al lenguaje blasfematorio conocerá un cierto recrudecimiento represivo tras la aplicación de los decretos tridentinos que marcarán la consolidación de la reforma religiosa en el mundo católico.

En los tiempos fuertes de la Contrarreforma la Iglesia encuentra en el poder civil un inestimable aliado en su cruzada represiva contra las blasfemias y demás conductas del desorden contrarias a la moral cristiana. Al menos esto es lo que se desprende de ciertas leyes elaboradas por algunas ciudades del Principado durante la segunda mitad del siglo XVI para combatir la inmoralidad de costumbres y los vicios de una sensualidad incontrolada. El 7 de mayo de 1581, el pregonero Pere Zacharies proclama trompeta en mano y a viva voz por las calles de Lérida un bando titulado Dels peccats publichs, dirigido a castigar los principales pecados públicos cometidos por los habitantes de la ciudad y localidades vecinas. El edicto se propone terminar con la tolerancia social de determinados comportamientos contrarios al buen orden político y religioso, muy enraizados en la vida cotidiana de los ilerdenses y municipios próximos. La represión se centra en cinco grandes aspectos: pecados de la lengua (blasfemias y juramentos); desorden sexual (amancebamientos, adulterios, prostitución); práctica ilícita del juego; castigo y expulsión de rufianes y vagabundos; actividades maléficas de brujos y supersticiosos. De todos ellos, el que reviste mayor gravedad es el vicio de jurar y blasfemar por ser la causa principal de que Dios descargue su cólera en forma de cataclismos imprevistos (inundaciones, terremotos, epidemias...) sobre las comunidades que toleren semejantes actitudes, siendo muchas veces las autoridades religiosas y laicas las responsables de las desdichas de sus conciudadanos al no poner el suficiente empeño en erradicar tan nefasta costumbre. El preámbulo del edicto se extiende en estas consideraciones:

«Ara que us fan a saber los mag.chs ss Cort i veguer, phers y prohomens de la ciutat de Leyda a tothom de qualsevol Grau, stamento condisio que sien com per esquivar y estripar e remoure los detestables enormes e illissits, o, horribles juraments e altres paraules lleges e nefandes contra la divina magt de ntre sor deu creador e redemptor e contra la purissima verge maria e sancts e sanctes del paradis e per altres enfinides abominations vicis e pecats e deffalliments los quals son radicats en la dita ciutat habitants e poblats en aquella per los quals pecats vicis abominations e deffalliments conve sostener al poble habitants en aquella fa sequedats mortalitats e altres fretares flagells tribulacions e altres molts afans les quals son molt males e a gran damnatio de aquells quie les atempten e les

${ }^{56}$ Serra Vilaró, J. 1936: 417.

Hispania Sacra, LXIV

130, julio-diciembre 2012, 525-564, ISSN: 0018-215X, doi: 10.3989/hs.2012.016 
cometen e pitjor a aquells qui les sostenen si com tractar les poden com per aquelles comeses a sostengudes deu sia offes e cauen quiscuns en ira de deu e per conseguent meresquen e aconsequesquen les dites tribulations». ${ }^{57}$

La disposición contra blasfemos va en primer lugar y está inspirada claramente en el ordenamiento legislativo real promovido bajo la monarquía de los Reyes Católicos y renovado en 1566 por el monarca Felipe II. Si bien se excluye la pena de muerte, el castigo no deja de tener una elevada dosis de crueldad con la mutilación de la lengua del condenado:

«Primerament que ninguna persona de qualsevol stament o, condisio sie home o dona no gossi o presumesca jurar ne blasfemar dels noms de ntr sor deu e la humil verge maria digna mare sua ne de sos sancts e sanctes de paradis e qui contratara hage de encorrer en pena de esser posat a la cadena en la plassa de la paheria ab un garfi en la llengua o sie en la boca e ultra aixo hagen de estar a merce dels dits cort i veguer pahers i prohomens». 58

Los castigos físicos tienden a desaparecer de las legislaciones locales catalanas a medida que avanza la Edad Moderna y el furor violento contrarreformista se apaga. En aquellos lugares donde se mantuvieron tenían más un carácter de ceremonia simbólica de ejemplificación moral colectiva y de sometimiento del blasfemo al oprobio público que no infringir daño corporal efectivo al condenado. En la población de Sant Llorens de Morunys, localidad situada al sur del macizo del Cadí en las estribaciones de los Pirineos, se castigaba a los blasfemos de la siguiente manera: De buena mañana se les conducía hasta la plaza principal del pueblo con las manos atadas a la espalda y una gruesa soga colocada alrededor del cuello tirada por un representante de la justicia local. Una

57 «Ahora os hacen saber los magistrados, Corte y veguer, y paers y prohombres de la ciudad de Lérida a todos de cualquier grado, estamento o condición que sean, como para esquivar, destripar y remover los detestables, enormes e ilícitos, o, horribles juramentos y otras palabras feas y nefandas contra la divina majestad de Nuestro Señor creador y redentor y contra la purísima Virgen María y santos y santas del paraíso y por otras infinitas abominaciones, vicios, pecados y desfallecimientos, los cuales están radicados en la dicha ciudad, y poblados en aquella por los cuales pecados, vicios, abominaciones y desfallecimientos conviene sostener al pueblo en aquella, provoca sequedades, mortalidades y otros flagelos, tribulaciones y otros muchos afanes, los cuales son muy malos y con gran condena para aquellos que los atentan o los cometen y pecan aquellos que los sostienen pues Dios está ofendido y caen en la ira de Dios, y por consiguiente merecen y consiguen las dichas tribulaciones» (AML, Arxiu Municipal de Lleida, Llibre de crides, Siglo XVI, Crida 126: 99-100). Agradezco encarecidamente a la profesora de la Universidad de Lérida, María José Vilalta el haberme proporcionado desinteresadamente tan valioso documento.

58 «Primeramente que ninguna persona de cualquier estamento o condición, sea hombre o mujer, no se atreva o presuma de jurar ni blasfemar de los nombres de Nuestro Señor Dios y la humilde Virgen María, digna madre suya, de sus santos y santas del paraíso, y el infractor incurra en la pena de ser encadenado en la plaza de la Paheria con un garfio en la lengua o sea en la boca, y además de esto haya de estar a merced de dicha Corte y veguer, pahers y prohombres» (Ídem). 
vez llegado allí, el reo era atado por el extremo de la cuerda a un poste situado en medio de la plaza (la picota), y así permanecía hasta bien entrada la noche recibiendo toda clase de burlas y vituperios por parte de los vecinos del lugar. ${ }^{59}$

Otras poblaciones también adoptaron la línea de castigar al blasfemo por vía del escarmiento y de la mofa pública, renunciando a la efusión de sangre de los castigos corporales. Se combinaban las multas con las humillaciones públicas de befa sin aparente riesgo para la integridad física del blasfemo. En el siglo XVII, la ciudad de Balaguer (Lérida) promulgó un edicto en el que se prohibían las palabras blasfemas e irreverentes cuyos destinatarios fueran Dios, la Virgen o los santos, ni tan siquiera en expresión jocosa, pública o privadamente. La prohibición no se limitaba al interior del recinto amurallado de la urbe, sino que se hacía extensiva a todo el perímetro del término municipal. El infractor recibía una multa cuya cantidad se determinaba por la importancia que se le otorgaba al insulto, a mayor gravedad mayor cuantía económica. Si el blasfemo no quería o no poseía los recursos financieros para abonarla sería prendido a la fuerza y arrojado vestido y calzado a la acequia que proporcionaba la energía hidráulica con la que funcionaba el molino de la localidad. ${ }^{60}$ Una ridícula pantomima teatral para regocijo del pueblo pero sumamente humillante para el desafortunado protagonista.

En otras partes de Cataluña ni los castigos corporales ni las representaciones burlescas parecen formar parte del repertorio legislativo local. En 1616, Juan Francisco de Gracia, visitador real en el Valle de Arán, publica un edicto contra juradores y blasfemos, distinguiendo las penas a aplicar para unos y otros. A los primeros se les impone en concepto de multa el pago de una libra de aceite para la iluminación del culto de la parroquia por cada vez que mentasen inapropiadamente el nombre de Dios, la Virgen o los santos. Los segundos recibían una sanción de sesenta sueldos, de la que una tercera parte iría destinada a alumbrar el ara del templo parroquial, otro tercio sería para beneficio de la curia real, y la restante se dividiría en dos: una para el denunciante y la otra para el «común del valle» (gobierno municipal). En el bando no se mencionan penas físicas ni exposiciones humillantes de escarnio en lugares concurridos por el gentío, tampoco se especificaban las palabras punibles de blasfemia. Una vez más el poder secular asocia los juramentos, los reniegos, las blasfemias de los malos cristianos como causas directas de las calamidades con las que el Creador celestial castiga a los súbditos del Principado:

«Por quanto Dios nuestro Señor por el detestable crimen de jurar, y blasfemar, han sembrado grandes plagas, y persecuciones a la tierra: Por tanto, se ordena, y manda, para

\footnotetext{
${ }^{59}$ Serra Vilaró. J. 1936: 417.

${ }^{60}$ Sanahuja, P. 1984. Historia de la ciutat de Balaguer: 342, Balaguer.
} 
que los juradores, y blasfemadores sientan alguna pena de tan gran ofensa que cualquiera persona, de cualquier grado, o condición, que sea, no blasfeme, ni jure por Nuestro Señor Dios, ni por la Santísima Virgen María, Señora, y Abogada Nuestra, ni por los Santos, en pena por cada vez, que juren de una libra de aceyte, aplicadora para el Santíssimo Sacramento de la parroquia, do será el tal jugador, y el blasfemo tenga pena de sesenta sueldos, aplicadoras la tercera parte para el Santísimo Sacramento, la otra tercera para la Regia Curia, y la otra parte, la mitad para el acusador, y la mitad para el Común del Valle».61

Los magistrados laicos parecen tratar con bastante condescendencia a los culpables de blasfemar. Los delitos de la lengua serían un asunto menor dentro de las preocupaciones diarias de las autoridades locales de muchos núcleos urbanos y rurales de la Cataluña del Antiguo Régimen. En la dirección indicada por Jesús María Usunáriz cuando dice que los tribunales civiles de la península se desentendieron de este delito. ${ }^{62}$ Las fuentes coetáneas señalan el distanciamiento entre la ley represora y su aplicación real. Sirva un ejemplo paradigmático. El Batlle de la corte judicial de Cardedeu, -municipio de la provincia y diócesis de Barcelona, situada no muy lejos de la capital catalana-, sancionaba en 1620 con una simple multa de cinco sueldos destinados a los gastos del culto parroquial a quien jurase o blasfemase de las potencias celestiales. ${ }^{63}$

Esta relajación de los jueces civiles probablemente obligase al virrey de Cataluña, Luis Díez de Aux Armendariz, -a la sazón obispo de la diócesis de Urgel- ${ }^{64}$ a publicar algunos años más tarde, en 1626, un edicto recordando la vigencia en el territorio del Principado de la legislación real contra blasfemos aprobada por los Reyes Católicos en 1492, con una disposición adicional por la que se castigaba con una multa de sesenta sueldos a la persona que no denunciase al blasfemo ante las autoridades:

«Y com per lo detestable crim de blasfemar, jurar e renegar de nostre Señor Deu, tramete nostre Señor grans plagues y persecucions en la terra. Per tant y altrament sa Excelencia volent que tant detestable crim y ofensa de Deu sia extirpat, y los juradors y renegadors sentan alguna pena de tanta ofensa procehint deliberació y conclusió en lo sacre Real Consell feta, diu y mana a totom generalmente, que ninguna persona de qualsevol estament, Grau, o condició que sia, no blasfeme ni altrament iure letjament per nostre Senyor Deu, y per la Santísima Verge Maria Señora y advocada nostra, ni per los sants,

${ }^{61}$ Ordinacions, pragmáticas y edictos reales del Valle de Arán, por el Doctor Juan Francisco de Gracia, visitador Real en el dicho Valle, 1616, Cap. XXXI: 215.

62 Usunáriz, J.M. 2006: 211.

${ }^{63} \mathrm{ADB}$ (Arxiu Diocesà de Barcelona), Archivo parroquial de Cardedeu, caja 65, Batlle, siglo XVII-XVIII, Registre de la Cort del Batlle de Cardedeu (1610-1626).

${ }^{64}$ Prelado originario de Ecuador, ocupó la silla episcopal de Urgel de 1622 a 1627. Perteneció a la orden cisterciense. Fue abad del monasterio de Oliva (Navarra), después obispo de Jaca, de donde pasó a la sede urgellense. Tras ser nombrado Virrey de Cataluña, finalmente fue designado arzobispo de Tarragona. 
sots pena quels será clavada la llengua, o serán açotats públicamente, o altra pena mayor o menor y qualsevol persona que tal blasfemia o jurament aura hoyt, que hajan a denunciar encontinente a la Regia Cort sots pena de sexenta sous». ${ }^{65}$

Sin embargo, una cosa era la letra escrita y otra muy distinta la realidad cotidiana. Los prelados reprochaban la aparente indiferencia de los magistrados civiles encargados de castigar este delito. La Iglesia exige de las autoridades laicas un mayor compromiso en perseguir y penar a los culpables de proferir blasfemias sin demandar la aplicación de castigos extremos que pusieran en peligro la vida del blasfemo. Los prelados lanzan la advertencia al brazo secular de la justicia que la desidia de muchos jueces en procesar y condenar los delitos de la lengua conlleva responsabilidades espirituales de las que tendrán que rendir cuentas ante el tribunal divino una vez extinguida su vida física. Las provisiones de visita pastoral escrituradas en el Principado durante el seiscientos y el setecientos repiten hasta la saciedad idéntica amonestación, destinada a alertar de los peligros a los que se expone la salud espiritual de la sociedad cuando reina la anarquía del más soez lenguaje blasfematorio por negligencia manifiesta de las autoridades judiciales locales. El 22 de febrero de 1752 el visitador episcopal de la diócesis de Vic rinde visita a la localidad de Sant Feliu Sarroca, y allí es informado de la enraizada costumbre que tienen muchos lugareños de aquella parroquia en maldecir e injuriar el nombre de Dios a la mínima contrariedad que se les presentaba. Para remediar esta situación, el delegado diocesano exhorta a la actuación urgente de la justicia civil para salvar las almas de los blasfemadores empedernidos, consignando por escrito lo siguiente:

«Aixi mateix tenim entés, que alguns individuos de esta parroquia olvidats de Deu, y de la salvació de sas animas, causan gran escandol ab sas llenguas infernals, proferint paraulas plenas de ira, malediccions, y blasfemias, ab que perturban la pau, y quietud de las casas en que habitan, ofenent las pias orellas dels cristians, y donant a menut mal exemple al poble: Perço exortam encaridament a las justicias estigan vigilants en refrenar sem-

\footnotetext{
65 «Y como por el detestable crimen de blasfemar, jurar y renegar de Nuestro Señor Dios, transmite Nuestro Señor grandes plagas y persecuciones en la tierra. Por tanto y porqué su Excelencia quiere que tan detestable crimen y ofensa de Dios sea extirpado, y los juradores y renegadores sientan alguna pena de tanta ofensa, procediendo, deliberación y hecha conclusión en el Sacro Real Consejo, dice y manda a todos generalmente, que ninguna persona de cualquier estamento, grado o condición que sea, no blasfeme ni jure feamente por Nuestro Señor Dios, y por la Santísima Virgen María Señora y abogada nuestra, ni por los santos, bajo pena que les será clavada la lengua, o serán azotados públicamente, u otra pena mayor o menor y cualquier persona que tal blasfemia o juramento oiga, vaya a denunciarlo enseguida a la Regia Corte bajo pena de sesenta sueldos (BC, Biblioteca de Catalunya, Follets Bonsoms, $\mathrm{n}^{\circ} .4868$, Edictes o cuides fetes y publicades per manament del excelentíssim Senyor Don Luys Díaz de Aux y de Armendariz per la gracia de Deu, y de la Santa Sede Apostolica, Bisbe de Urgell, Conseller, Lloctinent y Capitá General de la S.C y R.M en los Principat de Cathalunya y comptats de Roselló y Cerdanya, 1626).
} 
blants llenguas, y atacar estas, y qualsevol altras escandols, majorment quant son publichs, y los fem preseas que per rahó de son ofici tenen obligació de castigarho, y que si son omisos en cosas de tanta importancia serant responsables en lo Divino Tribunal, en que sels fará carrrech de las animas que per sa negligencia se hauran condemnat». ${ }^{66}$

¿Por qué razón la justicia civil se muestra tan remisa en perseguir y castigar a los blasfemos con la rigurosidad que se le exige?. ¿Qué se oculta detrás del desinterés de los jueces locales, perezosos por su falta de beligerancia en combatir los pecados de la lengua?. Probablemente las causas habría que buscarlas en el armazón mismo de la administración de justicia y en el corsé intimidatorio de la opinión pública, especialmente en ambientes rurales. Los delitos del lenguaje estarían sometidos a una serie de restricciones que harían difícil en la práctica la consecución del castigo ejemplarizante, igual que ocurría con los crímenes de violencia sexual en el Antiguo Régimen. ${ }^{67}$ De una parte, la indolencia de muchos jueces municipales en asumir los textos represivos impuestos por las ordenanzas reales. De otra, la impotencia administrativa de los tribunales locales para hacer frente a los numerosos procesos por blasfemia que habría de incoar si en verdad se pusieran manos a la obra, visto el elevado número de personas que habitualmente blasfemaban. A este respecto, la ineficacia de la justicia del brazo secular está extensamente condicionada por la actitud de apoyo, indiferencia o de resistencia de las personas comunes. La costumbre impone la tolerancia en una sociedad donde el mantener buenas relaciones vecinales es condición imprescindible de convivencia. La obligación de vivir en comunidad se acompaña de la discreción cuando se es interpelado por las autoridades religiosas o temporales en sus pesquisas por hallar culpables de blasfemar. Hay que convivir y soportar al vecino colérico, violento, pendenciero, impío o blasfemador. Sólo cuando los intereses particulares de un habitante de la parroquia se ven perjudicados por las desidias de otro morador del lugar con fama de blasfemo puede llegar la denuncia a los jueces. ${ }^{68} \mathrm{La}$ vida cotidiana transcurre como si cada persona renunciara a juzgar, al menos públicamente, el sentimien-

\footnotetext{
66 «Así mismo tenemos entendido, que algunos individuos de esta parroquia olvidados de Dios, y de la salvación de sus almas, causan gran escándalo con sus lenguas infernales, profiriendo palabras llenas de ira, maldiciones, y blasfemias, con que perturban la paz, y quietud de las casas en que habitan, ofendiendo las pías orejas de los cristianos, y dando a menudo mal ejemplo al pueblo. Por ello exhortamos encarecidamente a los justicias estén vigilantes en refrenar parecidas lenguas, y atacar estas, y cualesquiera otros escándalos, mayormente cuando son públicos, y que por razón de su oficio tienen obligación de castigarlo, y que si son remisos en casos de tanta importancia serán responsables en lo Divino Tribunal, en que se les responsabilizará de las almas que por su negligencia se hayan condenado» (AEV. Archivo Episcopal de Vic, Visitas pastorales, Libro 257, fol. 803).

67 Vigarello, G. 1999. Historia de la violación, XVI-XX, Valencia. 9: 393.

${ }^{68}$ Dyonet, N. 1998. «Impietés provinciales au XVIII ${ }^{\mathrm{e}}$ siècle», Histoire, économie et société,
} 
to religioso que el prójimo manifiesta de la religión, muchas veces por miedo a posibles represalias. Por esta razón, los vecinos fueran probablemente reacios a presentar denuncias contra blasfemos. ${ }^{69}$

\section{LA JUSTICIA EPISCOPAL}

La llamada en auxilio de los obispos a la justicia civil para que tuviera una actitud más contundente contra quienes vituperaban el nombre de Dios y de sus servidores, no se acompañaba, sin embargo, de una actitud marcadamente beligerante en la práctica de los jueces episcopales..$^{70}$

Desde finales de la Edad Media las distintas diócesis de Cataluña van publicando regularmente edictos contra la costumbre de blasfemar inspirados en la antigua ley romana del siglo XIII. ${ }^{71}$ Normativa general que inspirará la posterior legislación episcopal europea dirigida a combatir los pecados de la lengua. ${ }^{72}$ En el marco catalán las leyes eclesiásticas siguen al pie de la letra las instrucciones procedentes de Roma. El Concilio de Tarragona de 1339 ordena en su constitución 72 que la decretal del pontífice Gregorio IX reglamentando el castigo a aplicar a los blasfemos fuese leída por los rectores de las iglesias a los fieles en las fiestas de Navidad, Pascua, Ascensión, Pentecostés, Asunción y otras festividades de ámbito local. La asamblea conciliar recordó a las autoridades diocesanas y seglares la obligación de observar la disposición so pena de incurrir en grave desobediencia. ${ }^{73}$

\footnotetext{
${ }^{69}$ Ídem.

${ }^{70}$ Sobre la aplicación de la justicia eclesiástica en España son interesantes los trabajos recogidos en Aznar Gil, F (coord.), 2002, La administración de la justicia eclesiástica en España: Jornadas celebradas en Salamanca, 5 y 6 de febrero de 2001, Universidad Pontificia de Salamanca,

${ }^{71}$ La legislación canónica medieval fue muy estricta con los blasfemos. Desde el siglo XIII, las autoridades eclesiásticas seguían las directrices de una decretal del pontífice Gregorio IX del año 1236 promulgada dentro del Corpus Iuris Canonici, donde se ordenaba que el blasfemo permaneciese de pie ante la puerta de la iglesia durante siete domingos seguidos mientras se celebrasen los solemnes oficios de la misa. En el último, el reo se presentaría sin capa, descalzo y con una soga en torno al cuello, implorando a viva voz el perdón divino. Asociado a este humillante castigo, se imponía días de ayuno, multas y penas de cárcel, con la obligación añadida de dar limosna. Si el blasfemo rechazaba someterse a esta serie sucesiva de actos punitivos, se le prohibía entrar en la iglesia y era privado de recibir sepultura en tierra sagrada tras su fallecimiento.

${ }^{72}$ Leyes posteriores enriquecieron el arsenal represivo contra los blasfemos. En 1311, el sínodo de Ravena (Italia) declaró la exclusión de la iglesia a todo blasfemo durante el período de un mes, y si reincidía no podía ser sepultado en cementerios cristianos después de su muerte. Por su parte, el Concilio de París celebrado en 1429 castigaba este delito con cárcel y ayuno obligatorio a pan y agua durante ocho días, y al doble si persistían en la mala conducta.

${ }^{73}$ Llompart, G. 1972. «Blasfemias y juramentos cristológicos en la Baja Edad Media catalana», Hispania Sacra XXVII: 139.
}

Hispania Sacra, LXIV

130, julio-diciembre 2012, 525-564, ISSN: 0018-215X, doi: 10.3989/hs.2012.016 
Entre 1420 y 1430, el obispo de Barcelona, Francisco Climent Copera, elaboró una serie de artículos legislativos destinados a regir la vida religiosa de sacerdotes y laicos de su territorio diocesano (se desconoce el año exacto de su publicación). Este prelado, fallecido el 18 de diciembre de 1430, destacó no sólo por su celo pastoral en organizar solemnes procesiones e impresionantes rogativas con participación multitudinaria de fieles, sino también en su preocupación por asistir a los pobres de la diócesis. Los artículos recogen las principales preocupaciones de la jerarquía episcopal de la época: el trato entre cristianos y judíos; la denuncia de la usura y de los notarios y jueces que la consentían; la condena de las supersticiones y hechizos mágicos a los que se entregaban muchos cristianos; la violencia ejercida contra personas del estamento eclesiástico; los matrimonios clandestinos y las excomuniones a las que daban lugar; las demoras en pagar las cantidades que la gente dejaba en sus mandas pías o la controvertida cuestión del tráfico comercial con los musulmanes. El artículo noveno está dedicado a la represión de los blasfemos, declarándoseles anatemas con las penas espirituales accesorias de excomunión y privación de recibir cristiana sepultura tras su fallecimiento, si antes no se hubieran reconciliado con Dios cumpliendo las penitencias prescritas en el ordenamiento eclesiástico, consistentes en permanecer de pie siete domingos seguidos a la puerta de la iglesia, sin penetrar en su interior, ayunando siete viernes consecutivos a pan y agua, junto a otras penas expiativas si la autoridad religiosa pertinente lo considerase oportuno. La disposición no excluye el recurso a la fuerza de la justicia seglar para doblegar las voluntades obstinadas de los blasfemos más incorregibles con la aplicación de castigos corporales:

«Item vos denunciam que los malvats sacrileges e abominables peccadors blasfemen a Deu e a la Verge Maria o alguns dels sants, o reneguen o juren per lo cap, ventre o per altres membres dels publicament, jatsia que per les leys setglars hagen pena de mort, mas per la sgleya de Deu deven esser anathematizats e foragitats de aquella, ne en la seva mort deven haver eclesiástica sepultura si donchs en lur vida ne fan penitencia publica per set diumenges devant lo portal mayor de la esgleya, no entrant en aquella, e dejunant en pa e en aygua set divendres, e fer altres penitencies contingudes en las constitucions papals e provincials contra los dits sacrileges promulgades, als quals si mester fa deven esser forçats per los jutges temporals ab penas corporals». ${ }^{74}$

\footnotetext{
${ }^{74}$ «Item denunciamos que los malvados sacrílegos y abominables pecadores blasfeman de Dios y de la Virgen María o de algunos santos, o reniegan o juran por la cabeza, vientre o por otros miembros de él públicamente, por las leyes seglares han de recibir la pena de muerte, más por la Iglesia de Dios deben ser anatematizados y expulsados de aquella, y en su muerte no deben tener sepultura eclesiástica si en vida no han hecho pública penitencia durante siete domingos delante del portal mayor de la iglesia, en entrando en ella, ayunando a pan y agua durante siete viernes, y con otras penitencias contenidas en las constituciones papales y provinciales promulgadas contra los dichos sacrílegos, los cuales deben ser forzados por los jueces temporales con penas corporales» (Hillgarth, J.N. 1978-1979. «Articuli et monitiones» para los fieles de la diócesis de Barcelona publicadas entre 1420 y $1430 »$, Analecta Sacra Tarraconensia 51-52: 1-6.
} 
En esta línea, el día 30 de abril de 1491 el obispo de turno de la diócesis barcelonesa hace público otro edicto muy parecido contra blasfemos. ${ }^{75}$

Sin embargo, la vigilancia pastoral de los prelados del episcopado barcelonés no se acompañaba de una actividad procesal destacable contra los acusados de blasfemia. ${ }^{76}$ Los 1.939 documentos judiciales conservados en el archivo episcopal son la demostración de las diligencias procesales de los jueces eclesiásticos de la diócesis de Barcelona en el siglo XV.77 Sobresale la escasa presencia de denuncias por blasfemias, añadidas como una infracción agravante más al cargo acusatorio delictivo principal. En numerosos interrogatorios se pregunta a los testigos si el reo es de «conversación inhonesta» con la transcripción literal de las respuestas. Generalmente, las blasfemias son pronunciadas cuando se amenaza o se injuria. Así, en el proceso abierto en 1443 contra Mateu Des Foros, presbítero y beneficiado de la catedral de Barcelona, por proferir amenazas contra otros presbíteros, un testigo declara que el acusado gritó la siguiente blasfemia: «Per lo cul de Deu e de Sancta Maria, que ell castigaria lo dit Mossen Bonet, ell tester, e d'altres» (Por el culo de Dios y de Santa María, que él castigaría al llamado Mossen Bonet, y a otros). ${ }^{78}$ Un año después es juzgado por los mismos motivos Bernat Valls, rector de la parroquia de Canovelles, inculpado de conducta deshonesta (concubinato, agresión física, blasfemia, ser cabecilla de una banda armada, y no cumplir con los servicios religiosos).$^{79}$ Sólo encontramos un proceso incoado específicamente por blasfemia. En 1405, el clérigo Bernat Despí es acusado de escribir coplas deshonestas a la Virgen, las cuales envía desde la prisión a su procurador, Jaume Vila. De esta causa judicial solamente se han conservado los interrogatorios. 80

Los prelados siempre anteponían los castigos espirituales a las penas corporales. Ya desde el siglo XVI, los obispos del Principado son reticentes a la hora de endurecer las penas relacionadas con los pecados de la lengua según las nuevas directrices emanadas de la jerarquía romana favorecidas por los vientos de la Contrarreforma. Los titulares de las mitras catalanas mantienen sobre este

\footnotetext{
75 ADB (Archivo Diocesano de Barcelona), Registra Communium, 1487-1494: fol.119.

76 Martí Bonet, J. M. 1984. Processos de l'Arxiu Diocesà de Barcelona, Col. Cataleg-inventari d'arxius eclesiàstics de Catalunya, 1, Generalitat de Catalunya, Barcelona.

77 Serrano Seone, Y. 2006. «El sistema penal del tribunal eclesiástico de la diócesis de Barcelona en la Baja Edad Media», Clio\&Crimen 3: 334-429. La autora advierte que estamos ante una muestra representativa de las causas vistas por el tribunal eclesiástico de Barcelona durante el siglo XV aunque existen importantes evidencias que hacen pensar en pérdidas documentales. Además, no se conserva ninguna serie documental auxiliar como registros de sentencias que pudiera proporcionar información complementaria.

78 ADB (Archivo Diocesano de Barcelona), Proceso ${ }^{\circ} 872$.

79 Ibídem, Proceso n ${ }^{\circ} 902$

${ }^{80}$ Ibídem, Proceso $\mathrm{n}^{\circ} 80$
} 
asunto una actitud que recuerda mucho la prudencia y el escepticismo de la que hacían gala frente a otras manifestaciones heterodoxas de la cultura popular como la brujería y las supersticiones. Las autoridades religiosas episcopales y los misioneros apostólicos en sus campañas evangelizadoras itinerantes no atizaban el fuego del odio en sus prédicas doctrinales contra quienes profanaban con sus blasfemias la dignidad divina, ni tampoco excitaban las conciencias de los magistrados laicos para que la maquinaria judicial erradicara violentamente la costumbre de blasfemar de las bocas de sus convecinos. En el terreno práctico hay un claro distanciamiento entre las severas leyes adoptadas por la curia pontificia romana desde principios del siglo XVI con inclusión de la pena de cárcel perpetua y galeras, ${ }^{81}$ añadiéndose posteriormente los castigos corporales y el enclavamiento de la lengua, ${ }^{82}$ de las aplicadas por los obispos de la provincia eclesiástica tarraconense a partir de las mismas fechas, más partidarios de la aplicación doctrinal de los cánones penitenciales de San Carlos Borromeo (1538-1584) en su lucha contra los blasfemos, ${ }^{83}$ cánones que ganarán especial influencia en el mundo católico hispano a partir del siglo XVII ${ }^{84}$ La teología medieval domina ampliamente los espíritus de los contrarreformistas católicos del Principado a la hora de decidir cuáles eran los procedimientos más adecuados para luchar eficazmente contra las expresiones blasfemas. Se prefería coaccionar al blasfemo con la terrible arma moral de la amenaza de la excomunión como procedimiento expeditivo para atemorizar las conciencias de los blasfe-

${ }^{81}$ Disposición adoptada en el V Concilio de Letrán - magna asamblea conciliar de toda la cristiandad abierta por el Papa Julio II en mayo de 1513 y clausurada por su sucesor León X en marzo de 1517-, dentro del mandato Supernae Dispositionis.

${ }^{82}$ Iglesia y Estado aproximan posiciones en el ámbito jurídico. La legislación canónica endurece notablemente las leyes represoras contra los blasfemos. Durante el pontificado de Julio II (1550-1555) se aprobaron las mutilaciones corporales para los convictos de blasfemia recalcitrantes, una medida que los pontífices de la Edad Media rehusaron siempre aplicar. Los sucesores en la silla de San Pedro recogieron en sus nuevas leyes la dureza de los castigos, aunque raras veces se aplicaron.

${ }^{83}$ Básicamente son una adaptación de la legislación eclesiástica medieval al plano catequético. El cardenal y arzobispo de Milán distingue dos categorías principales en los pecados de la lengua: el falso juramento y la blasfemia. A cada una le corresponden diversas penas espirituales en función de su gravedad. El perjuro es castigado con penitencias que van de uno a diez años, aunque en ciertos casos el período penitencial se fija en tres cuaresmas; ayunos de cuarenta días a pan y agua, prolongados de por vida a todos los viernes del año si la importancia del perjurio lo requiere; venta de los bienes patrimoniales del perjurador, entrega de los beneficios gananciales a los pobres e ingreso en un monasterio hasta el fin de sus días; privación del sacramento de la eucaristía durante un año. Para castigar las blasfemias prescribe ayunos, penitencias públicas, obras de caridad y pago de multas (Borromeo, C. 1768. Instrucciones de San Carlos Borromeo sobre la administración del Sacramento de la Penitencia con los cánones penitenciales: 81-85, Madrid).

${ }^{84}$ Sobre las repercusiones intelectuales del pensamiento del prelado italiano en España ver: González Novalín, J. L. 1988. «San Carlos Borromeo y su relación con España», Hispania Sacra, Vol. 40, no 81:193-204; Huerga, A. 1988. «La irradiación de San Carlos Borromeo en España a principios del siglo XVII», Hispania Sacra, Vol. 40, nº 81: 179-191. 
madores más empecinados. ${ }^{85}$ La expulsión de la comunidad de cristianos implicaba la muerte espiritual y también social de la persona que persistía en sus errores con contumacia y rebeldía. El individuo privado de recibir los sacramentos y demás beneficios espirituales y eclesiásticos sólo podía esperar la condenación eterna de su alma en las llamas del infierno. La Iglesia opta por la vía de reintegrar al enemigo de Dios en la comunidad de los fieles católicos si renuncia sinceramente al vicio de blasfemar, con el recurso de la ayuda de la justicia seglar para resolver los conflictos originados por la disidencia doctrinal al dogma cristiano si fuera preciso.

A este respecto, las constituciones sinodales del obispado de Urgel correspondientes al año 1557 en su título XXV excluyen a los blasfemos de la asistencia a los actos de culto eclesiástico, y a todas las gracias espirituales proporcionadas por la Iglesia, sin antes ser penitenciados y absueltos de su pecado conforme a las leyes escrituradas en el derecho canónico. Se les imponía penitencia pública y una multa de siete sueldos destinada a obras pías como las dos condiciones indispensables para ser reintegrados dentro de las filas de los cristianos. La institución eclesiástica diocesana se reservaba el derecho a aplicar penas más graves a los blasfemos porfiados en el vicio. Para ello, la asamblea sinodal solicitaba la ayuda de las autoridades y jueces laicos en su guerra sin cuartel contra las palabras blasfemas. Una vez más los prelados advierten que la denegación de auxilio o el desinterés del poder temporal sobre este asunto podría desatar la cólera divina en forma de sequías, plagas, hambres y otros flagelos con los que Dios expresaría su enojo por la falta de colaboración. La relación binaria mal moral-mal físico pregonada por la teología escolástica se nos aparece aquí en todo su esplendor. La constitución pone especial énfasis en la complicada situación social por la que atravesaba la diócesis urgellense en aquellos turbulentos años, marcados especialmente por la presencia de partidas de bandoleros entregados al robo y al crimen que incrementaban notablemente el clima general de miedo e inseguridad entre la gente:

«Mandamos a los rectores y vicarios que no admitan a los divinos oficios a los que públicamente ovieren dicho pese, o reniego, descreo, fetge, cul de deu; o blasfemare el nombre santísimo de Dios o de Nuestro Senyor Jesucristo o de su gloriosíssima Madre o de otros santos o santas o ángeles, maldiciendo, escarneciendo o diziendo palabras inju-

\footnotetext{
${ }^{85} \mathrm{Al}$ contrario de lo que podría pensarse, la gran mayoría de las excomuniones tienen su origen en cuestiones económicas. Los motivos no tienen necesariamente que ver con temas de carácter doctrinal, ni de incumplimiento de los preceptos de la práctica religiosa. En muchos casos son asuntos de estricta índole económica: impago de bulas, censos, censales, diezmos, no cumplir con los legados testamentarios y deudas en general. El excomulgado era rehabilitado una vez satisfecha la deuda. Sobre el rito de la excomunión y su repercusión en la sociedad europea de la Baja Edad Media y del Renacimiento ver el libro de V. Beaulande, V. 2000. Le malheur d'être exclu? . Excommunication, réconciliation et société à la fin du Moyen Âge, Publications de la Sorbonne, Col. Histoire ancienne et médiévale 84, París.
} 
riosas en general o particular, o por otra cualquiera manera, expresse o tácitamente, o con cualquier color o palabras encubiertas; hasta tanto que hayan hecho penitencia pública que manda el derecho y está notado en el cuarenta un caso penitencial, y tengan absolución o ayan primero pagado y dado siete sueldos, y aquellos sean repartidos en obras pías o dado al hospital del lugar por el cura y uno de los cónsules juntamente, y tengan absolución; sobre lo qual los encargamos la conciencia; y si fuéremos avisados que no ay enmienda en tan grandíssimo pecado, según la calidad de las personas y enormidad del delito, lugar, tiempo y otras circunstancias, nos o nuestro vicario general o nuestros officiales agravaremos las penas antes que las disminuyamos, asenyaladamente contra aquellos que fueran incorregibles y otras veces huvieren sido condenados.

Y por honra y servicio de Nuestro Senyor, rogamos encarecidamente y encargamos las consciencias a los vegueres, bayles, cónsules y otros cualesquiera officiales seculares, den todo el favor y fuerças que dellos confiamos; y se precian de ser cristianos y temen las penas y castigos que da Dios a los pueblos que no se reconocen y no le honran en general y particular, y ansi padecen mortalidades, pestilencias, hambres o carestía de los mantenimientos, o bandos, homicidios, o ladrones los roban, o bandoleros les comen sus haziendas, y otros infortunios que padecen muchos lugares desta diócesis». ${ }^{86}$

A lo largo del siglo XVII las leyes eclesiásticas de los diversos obispados de Cataluña contra los blasfemos apenas experimentan variación. Los juramentos y las blasfemias se encuadran dentro de las manifestaciones de impiedad religiosa que conviene reprender públicamente desde el púlpito, y son denunciados en los carteles clavados en las puertas de los templos donde se enumeraban los principales pecados más frecuentes de los seglares de la diócesis contra Dios y la Iglesia, como puede constatarse en el contenido del título X, capítulo XXI del Edicto de prohibición de pecados publicado por el obispado de Lérida en 1691 , texto de obligada lectura en todas las localidades de la sede diocesana durante todos los primeros domingos de la Cuaresma de aquel año:

«Si sabéis que algunos tengan costumbre de jurar, y blasfemar al nombre de Dios, y de sus santos, o que con ánimo endurecido viven descomulgados, sin querer absolverse, y obedecer a la Iglesia, o que no se han confesado, por lo menos una vez al año, y no han comulgado por Pascua Florida, o que no oyen Missa, y quebrantan públicamente los días de precepto...».

En el plano estrictamente legislativo la iglesia de la Cataluña del Antiguo Régimen realizó pocas aportaciones al marco legal jurídico precedente establecido por las autoridades romanas anteriores al Concilio de Trento donde se excluía la aplicación de castigos corporales. Las únicas innovaciones las hallamos en la cuantía de las multas con las que era castigado el blasfemo. El sínodo diocesano de la archidiócesis de Tarragona de 1704 aprobó multar con diez libras a

${ }^{86}$ Moliné, E. 1988. «Sinodes d’Urgell del segle XVI», Urgellia 16: 458-459.

Hispania Sacra, LXIV

130, julio-diciembre 2012, 525-564, ISSN: 0018-215X, doi: 10.3989/hs.2012.016 
la persona que blasfemase. ${ }^{87}$ Otras disposiciones semejantes fueron aprobadas por los eclesiásticos reunidos en sendas asambleas sinodales.

Uno de los indicadores más fiables para cuantificar la actividad de la justicia eclesiástica contra los blasfemos en Cataluña lo constituyen las escrituras de los procesos criminales del dominio señorial del Abad de Poblet. Poblet fue uno de los más importantes señoríos eclesiásticos del Principado hasta su exclaustración en 1835, consecuencia de la desamortización de Mendizábal. La abadía cisterciense controlaba un extenso territorio de centenares de kilómetros cuadrados, centrado en el norte, oeste y sur de Cataluña, en las provincias de Tarragona y Lérida, con jurisdicción sobre treinta y cinco localidades, situadas, en su mayoría, en las actuales comarcas de La Conca de Barberà, Alt Camp, La Segarra, les Garrigues, l'Urgell, y la Noguera. A estos territorios se le añadían granjas, términos despoblados y bienes inmuebles diseminados por toda la geografía catalana, incluida la capital. En la numerosa documentación conservada no existen denuncias ni procesos a blasfemos, sólo hay noticias de edictos y algún pleito sobre atribuciones de competencias judiciales entre los municipios y el Abad. ${ }^{88} \mathrm{La}$ administración de justicia del cenobio cisterciense ofrece uno de los ejemplos más paradigmáticos de la contradicción entre los deseos del clero de reformar el lenguaje bruto de la gente y la escasa rigurosidad de su legislación represora. La prudencia eclesiástica a la hora de aplicar justicia junto a la falta de cooperación de las autoridades municipales frena cualquier iniciativa seria de reforma en el ámbito del mal hablar.

La ley más severa es publicada el martes 25 de noviembre de 1483, bajo mandato del Abad Joan Coello. La orden establece que el blasfemo contra Dios y la Virgen permaneciera tres días de ayuno a pan y agua encerrado en el granero u otro lugar del municipio donde estuviera incomunicado; si la blasfemia fuera dirigida contra algún santo se le aplicaría una multa de seis dineros destinada a la iluminación de la iglesia parroquial y a besar el suelo trazando una cruz con la boca por cada vez que lo repitiera:

«Si es troba algu que jura del nom de Deu o de la Verge, el cercenari o desordenat será posat en la sitja a dejuni de tres dias a pa i aigua. La pena no será remesa com per esguard de tan gran delicte encara es poca. Si jura del nom de sant o Santes, pagará 6 diners per cada cop i besará terra fent-hi una creu. Els 6 diners aniran per la lluminaria de cada lloc». .9

\footnotetext{
${ }^{87}$ Constituciones synodales Tarraconenses, Tit. XXXV. Const. I. fol, XXXV.

${ }^{88}$ Los resúmenes de los procesos criminales del señorío eclesiástico de Poblet están recogidos en el primer volumen de la obra del historiador Gual Vilà, V, 2003. Justicia i terra, La documentació de l'arxiu de Poblet, Vol. I, Valls. El segundo está dedicado a los procesos civiles: Gual Vilà, V, 2007. Poblet, senyor feudal. La documentació de l'arxiu de Poblet, Vol. II, Valls.

${ }^{89}$ Gual Vilà, V. 2007: 696 (Armari II, Calaix 31, Doc. 2).
} 
Hasta la segunda década del siglo XVII no se encuentra otra disposición legislativa contra blasfemos. El 16 de noviembre de 1616 el Abad Simò Trilla modera sensiblemente el castigo y prescinde de distinciones: jurar en el nombre de Dios, la Virgen y de los santos se castiga con multa de cinco sueldos y otras penas accesorias si el jurador persevera en su actitud..$^{90}$ Casi veinte años más tarde, en octubre de 1636, el Abad Jaume Pallarès manda que los blasfemadores sean castigados con una sanción económica de una libra destinada a la administración de la cofradía del Santísimo Sacramento; la misma pena recibirían las personas que no lo denunciaran..$^{11}$ La misma ley se repite de nuevo en 1702 con el Abad Josep Tresánchez. ${ }^{92} \mathrm{Si}$ alguna autoridad civil estuviera tentada en algún momento de promover a iniciativa propia un endurecimiento de penas, el poder espiritual hacia prevalecer sus derechos exclusivos jurisdiccionales en materia legislativa criminal y civil. La justicia eclesiástica aborta cualquier intento o presión local para introducir los castigos físicos prescritos en las leyes civiles. El 10 de marzo de 1579, el battle del municipio de Tragò manda pregonar un bando en la plaza mayor del pueblo donde, entre otras disposiciones, se impone a los blasfemos pena de cárcel de diez días, la primera vez, y enclavamiento de lengua, la segunda. ${ }^{93} \mathrm{La}$ nueva ordenanza fue rápidamente abortada por la autoridad eclesial.

La ausencia de causas judiciales no determina que la gente no blasfemara, simplemente las autoridades locales se mostraban remisas en la persecución del delito. Los reos no eran juzgados por blasfemar, los insultos se inscriben en un procedimiento penal de naturaleza distinta (robos y agresiones entre vecinos, pleitos territoriales, disputas económicas, etc.). En las declaraciones de encausados y testigos quedaba probado de sobras cómo habían renegado de Dios y de Santa María en el transcurso de las discusiones, sin suponer ello un cargo agravante. El 14 de octubre de 1536, Antoni Esquirol, un payés de la parroquia de Butsenit, en el curso de una trifulca con un vecino invoca el culo de Dios sin ningún pudor: «A culdedeu aixi van los bandolers en aquesta terra». ${ }^{94}$ El impúdico personaje ni siquiera fue amonestado.

\footnotetext{
90 Ibídem: 725 (Armari II, Calaix 32, Doc. 6).

${ }^{91}$ Ibídem: 727 (Armari II, Calaix 32, Doc. 7).

92 Ibídem: 692 (Armari II, Calaix 31, Doc. 7).

93 Ibídem: 383 (Armari II, Calaix 23).

94 Ibídem: 60 (Armari II, Calaix 6, Doc. 6).
} 
El Tribunal de Barcelona contra los Blasfemadores: AlgunOS DATOS eSTADÍSTICOS

En España, los inquisidores no dedicaron mucho tiempo y esfuerzos a la represión del blasfemo. Nunca se les consideró gente peligrosa que representara una potencial amenaza a los cimientos ortodoxos doctrinales de la Iglesia institucional. Prueba de ello es la opinión expresada por el inquisidor del Santo Oficio de Toledo, Isidro San Vicente a mediados del siglo XVII, en tiempos del Inquisidor General Arce Reinoso: «Los blasfemos aunque reincidan muchas veces nunca vienen a ser más que levemente sospechosos y así solamente abjuren de levi». ${ }^{95}$ Un criterio compartido por la gran mayoría de los inquisidores españoles. Para la Inquisición las blasfemias eran un delito menor dentro de los errores contra la fe cristiana. ${ }^{96}$ El Santo Oficio se ocupó de los blasfemos cuando los considerados mayores crímenes contra la fe, judaísmo y luteranismo, ya no planteaban problemas. ${ }^{97}$

El tribunal de Barcelona empezó a perseguir blasfemos cuando la fiebre antijudaica de finales del siglo XV y primeros años del XVI se había extinguido. El pico de mayor actividad represor contra blasfemos se sitúa entre los años 1552-1580, durante los tiempos duros de la Contrarreforma católica. ${ }^{98}$ A partir de entonces el celo de los inquisidores desciende hasta iniciar una nueva alza hacia 1610, para volver a bajar significativamente en la siguiente década, manteniéndose estable hasta 1640, cuando la persecución de este delito caiga a niveles mínimos, -consecuencia de los violentos acontecimientos sociales que dieron lugar a la Guerra del Segadors, con la huida precipitada de los inquisidores de la ciudad y el posterior asalto del palacio inquisitorial el día de Nochebuena de ese año-,situación que se mantendrá prácticamente inamovible hasta fines del siglo XVIII con algunos leves aumentos en 1670 y $1730 .{ }^{99} \mathrm{El}$ desglose por siglos da el siguiente resultado: en el siglo XVI se abrieron 120 procedimientos penales (106 hombres y 14 mujeres); 102 en el XVII ( 97 hombres y 5 mujeres); en el siglo XVIII se recuentan 18 (16 hombres y 2 mujeres). Por se-

\footnotetext{
${ }_{95}$ Blázquez Miguel, J. 1990: 232.

${ }^{96}$ Stephen Haliczer piensa que una de las causas de la falta de beligerancia de los inquisidores españoles contra el delito de blasfemia radica en la poca rentabilidad económica que podía reportar a la institución: «Dado el ambiente de competencia y los escasos beneficios que se podían extraer de tales casos, la Inquisición demostró poco interés en ellos y supusieron una parte ínfima de su actividad» (Haliczer, S. 1993. Inquisición y sociedad en el reino de Valencia (1478-1834): 469, Edicions Alfons el Magnanim, Generalitat Valenciana).

${ }^{97}$ Dedieu, J-P. 1985: 216.

${ }^{98}$ Sobre la actividad estadística inquisitorial del tribunal de Barcelona sobre los blasfemos y todos los demás delitos punibles de persecución ver Blázquez Miguel, J, 1989. «Catálogo de los procesos inquisitoriales del tribunal del Santo Oficio de Barcelona», Espacio, Tiempo, Forma, serie IV, 3: 11-156. ${ }^{99}$ Blázquez Miguel, J. 1990: 234.
} 
xos, 219 varones y 21 mujeres. ${ }^{100} \mathrm{El}$ estamento religioso tampoco se salvó de la rigurosidad de los inquisidores: 9 miembros del clero secular y 2 pertenecientes al regular (un sacerdote mercedario y otro de la orden de los paúles) tuvieron que vérselas con los jueces. ${ }^{101} \mathrm{La}$ distribución geográfica de los acusados se concentra mayoritariamente en los centros urbanos con Barcelona a la cabeza, 51 personas; seguidos a mucha distancia por Perpiñán (6), Tarragona (5) y Gerona (4), a los que hay que añadir alguna localidad comarcal importante del interior de Cataluña como Balaguer (Lérida) con 7 procesados. El resto de los enjuiciados se distribuyen un poco anárquicamente por todo el territorio catalán. ${ }^{102}$ Las profesiones que aparecen más veces en los pliegos de acusación corresponden a dos colectivos: labradores y militares, con 39 y 18 miembros respectivamente; a considerable distancia le siguen todo un conglomerado heterogéneo de comerciantes, artesanos y trabajadores de la más amplia diversidad de oficios (mercaderes, sastres, tejedores...) y hasta un verdugo. ${ }^{103}$ No consta que fuera procesado ningún noble por blasfemo, pero si ciertos profesionales liberales: cirujanos (3), abogados (1), escribanos (1), notarios (1). ${ }^{104}$ La inmensa mayoría de sentencias tuvieron un carácter leve, ${ }^{105}$ y consintieron en penas espirituales y multas.

Si se desciende al detalle, el abanico de posibilidades era amplio. Estas podían consistir en penitencias de carácter privado: en todos los casos reprensión severa y auto particular de fe con abjuración de levi; oír una misa en la sala donde se dictara la sentencia, descalzo, revestido con los ropajes de la infamia e insignias de blasfemo (sambenito, coroça y soga) y una mordaza en la boca. Al término de la cual sería absuelto en confesión y recibiría el sacramento de la comunión como acto de su reconciliación con Dios. Otros convictos por blasfemia eran condenados a la pena espiritual de rezar la tercera parte del rosario

100 Mis datos no concuerdan aquí con los de Juan Blázquez Miguel que da la cifra de 222 hombres y 18 mujeres.

101 Blázquez Miguel, J. 1990: 346.

102 Ibídem: 234.

103 Ibídem: 235-236.

104 Ídem.

105 De las 240 causas consignadas por blasfemia en las Relaciones de Causas de Fe elaboradas entre 1552 y 1799 , se desconoce la pena en 61 casos, y en otro el procedimiento judicial tuvo que suspenderse por fallecimiento del encausado. Otras 22 fueron dejadas en suspenso, cifras que representan un porcentaje cercano al 12'39 por ciento de las 178 resoluciones judiciales conocidas. Los absueltos fueron 8 , el 4'4\%; los desterrados 27 , el $15^{\prime} 1 \%$; los multados 31 , el 17'4\%; los penitenciados 28 , el $15^{\prime} 7 \%$; los reprendidos 43 , el 24'1\%; los recluidos en un monasterio 4, el 2’2\%. Los castigos más severos recayeron en 11 reos con azotes y destierro, el 6'1\%; a los que hay que añadir 3 que recibieron azotes y trabajos forzados en galeras. En porcentaje estadístico el delito de blasfemia representa el 4’4\% de los 5.425 causas judiciales examinadas por los inquisidores de aquel distrito (Blázquez Miguel, J. 1990: 233). 
todos los sábados durante un período de tiempo que podía fluctuar de uno a tres años desde la primera semana de la publicación del fallo judicial.

Otras penas eran de índole pública: lectura de la sentencia condenatoria en Auto de Fe general; oír una misa en la iglesia de su parroquia o en otro templo designado por los inquisidores (a menudo la iglesia de los dominicos de Santa Caterina de Barcelona), o monasterio (Montserrat es uno de los lugares predilectos para el envío de las almas descarriadas) en un día de fiesta de guardar ataviado con las ropas penitenciales reveladoras de su pecado ignominioso y el instrumento de hierro fijado a su lengua; servir a las necesidades de un establecimiento religioso durante un año sin cobrar estipendio alguno; destierro del lugar habitual de residencia, comarca o incluso del ámbito territorial del distrito jurídico de la Inquisición de Barcelona por un período determinado de tiempo que podía prolongarse hasta los siete u ocho años. Mucho más raras son las resoluciones judiciales que llevan aparejadas trabajos forzados para el Estado: trabajar en la ciudadela militar de Barcelona; servir en los astilleros navales de la misma ciudad en un período no inferior a un año o remar en las galeras del monarca durante un máximo de cinco o seis años. Asimismo se contabilizan algunas condenas que llevan aparejadas la reclusión en cárceles de la península o en algunos de los presidios de las plazas españolas del norte de África. La institución inquisitorial en Cataluña fue reacia a infligir castigos físicos a los blasfemos. Cuando se aplicaban las penas más rigurosas consistían en azotes recibidos en la vía pública. La sentencia más dura fue inflingida a un condenado en 1569 , azotes y seis años remando a la fuerza en las naves del rey. ${ }^{106}$ No se contabiliza ningún caso de prisión perpetua.

Los datos estadísticos del Santo Oficio de Barcelona ofrecen informaciones interesantes. Es un delito abrumadoramente masculino, característica común al resto de los tribunales españoles. La represión inquisitorial contra la blasfemia se cebó fundamentalmente en gente que vivía en la capital catalana con pequeñas ramificaciones hacia otros centros urbanos de mucha menor envergadura. Las zonas rurales sufrieron poco los rigores represores de la Inquisición a excepción de alguna población relevante. Los habitantes de amplias áreas del centro, noroeste y sur de la Cataluña rural apenas fueron molestados por los inquisidores. La distribución geográfica del delito confirmaría la opinión de Henry Kamen acerca de una de las características principales del tribunal en el Principado: la Inquisición centró su labor procesal sobre hombres y mujeres que habitaban en las grandes ciudades (Barcelona centralizó las tres cuartas partes de los procesados), mientras que el campo catalán estuvo poco afectado por la severidad del Santo Oficio durante la larga Contrarreforma. La extensión

\footnotetext{
106 Ídem.
} 
del territorio, los accidentes geográficos, las pésimas comunicaciones con abruptos caminos y la presencia de bandoleros prestos al asalto explicarían la predilección de los inquisidores en juzgar a ciudadanos de urbes e ignorar a los vecinos de pueblos y aldeas. ${ }^{107}$ Ello explicaría, quizás, la poca dedicación de la Inquisición de Barcelona a la represión de los blasfemos, al contrario de lo que sucedía en otros tribunales peninsulares donde la persecución a los blasfemos representaba una parte sustancial de su actividad, 108 ya fuera por denuncias $o$ autodelaciones. ${ }^{109}$

\section{CONCLUSIONES}

Los delitos de palabra tuvieron poca relevancia en la actividad judicial de los tribunales laicos y eclesiásticos en Cataluña. La dura legislación civil raramente se aplicó con todo su rigor sobre los convictos de blasfemia. La rigurosidad represiva de los textos legales se quedó en letra impresa. Unas leyes que a nivel local tienden claramente a suavizarse desde el siglo XV, reduciéndose los castigos corporales, e incorporando cada vez más las penas monetarias como medio para redimir el pecado cometido. En el período fuerte de la Contrarreforma parece que las autoridades municipales abandonan su laxismo y recrudecen con amenazas su intención de perseguir implacablemente a los blasfemos, actitud que en la realidad no pasa de ser un ejercicio de intenciones. En el plano práctico, la justicia civil de muchos pequeños municipios catalanes fue remisa en incoar procedimientos procesales a blasfemos, probablemente a causa de la desmesurada costumbre de blasfemar de muchos de sus vecinos, y así frenar potenciales conflictos comunitarios. Los jueces civiles prefirieron inhibirse del asunto en favor de los tribunales episcopales e inquisitoriales.

Una justicia episcopal que nunca se distinguió por su combatividad a la hora de juzgar a blasfemadores. En Cataluña, los obispos y señores eclesiásticos con jurisdicción penal fueron muy reticentes en castigar severamente con penas físicas a los culpables de delitos verbales, y parecen ser excepcionales las causas juzgadas exclusivamente bajo este cargo acusatorio, sin intervenir otras imputaciones de mayor gravedad. La jerarquía diocesana prefirió utilizar métodos disuasorios que no empleasen la coerción física y que privilegiaran, por el

\footnotetext{
${ }^{107}$ Kamen, H. 1998: 235-236.

108 Jean-Pierre Dedieu dice que ello es una característica común de los tribunales de Sevilla, Valladolid, Calahorra y Llerena (Dedieu, J-P. 1985: 210).

${ }^{109} \mathrm{~A}$ lo largo del siglo XVI, el tribunal de Logroño conoce un aumento significativo de autodenuncias (Queipo de Llano, M. T. 1999. «La disciplina del lenguaje blasfemo» en J. L. Pereira y J. M. Gónzalez Beltrán (eds.), en V Reunión Científica. Asociación Española de Historia Moderna: 541-548, Universidad de Cádiz-AEHM.
} 
contrario, la pedagogía religiosa, combinando la seducción del sermón evangelizador con el temor del infierno en una clara invitación a la autodelación espontánea. Por su parte, la Inquisición estaba muy lejos de controlar las desviaciones religiosas al dogma católico en la Cataluña rural. Los visitadores inquisitoriales no mostraban excesivo interés en adentrarse en localidades situadas en geografías abruptas y montañosas donde era muy difícil desplazarse y los peligros acechaban. A esto habría que añadir posiblemente la cautela de una comunidad temerosa por la inquietante aparición de un extraño que exige conocer sus pecados privados. Esta situación favorecía que la ingente cantidad de expresiones blasfemas y toda la sarta conocida de maldiciones e injurias del repertorio de la cultura popular estuvieran bien vivas, pese a las políticas de reforma moral emprendidas por muchos prelados del Principado.

\section{BIBLIOGRAFÍA CITADA}

Alonso-Guillaume, A. 1989. «Justice royale et oligarchies urbaines en Castille à travers les pétitions de Cortes (1518-1538)», Mélanges de la Casa de Velázquez 25: 103-120.

Bada, J. 1970. Situació religiosa a Barcelona, Barcelona.

Baquero-Moreno, H. 1976. «Injurias e blasfemias proferidas pelo homen medieval portugués na sua vida de relaçao social», en Tensoes sociais em Portugal na idade media: 77-93. Oporto.

Beaulande, V. 2000. Le malheur d'être exclu?. Excommunication, réconciliation et société à la fin du Moyen Âge, Publications de la Sorbonne, Col. Histoire ancienne et médiévale 84.

Belmas, E. 1989. «La montée des blasphèmes du Moyen Âge au XVIIe siècle», en J. Delumeau (ed.), Injures et Blasphèmes: 13-33, París.

Benedicti, J. 1601. La Somme des péchés et le remède d'iceux, París.

Blázquez Miguel, J. 1989. «Catálogo de los procesos inquisitoriales del tribunal del Santo Oficio de Barcelona», Espacio, Tiempo, Forma, serie IV, 3: 11-156.

Blázquez Miguel, J. 1990. La Inquisición en Cataluña. El tribunal del Santo Oficio de Barcelona, 1487-1820, Toledo.

Borromeo, C. 1768. Instrucciones de San Carlos Borromeo sobre la administración del Sacramento de la Penitencia con los cánones penitenciales, Madrid.

Cabantous, A. 1998. Histoire du blasphème en Occident (XVI ${ }^{e}$-XIXe siècle), París.

Caro Baroja, J. 1986. El Señor Inquisidor y otras vidas por oficio, Madrid. 
Casagrande, C. Vecchio, V. 1999. Les péchés de la langue. Discipline et éthique de la parole dans la culture médiévale, París.

Dedieu, J-P. 1985. «El modelo religioso: las disciplinas del lenguaje y de la acción», en B. Bennassar (ed.), La Inquisición española: 208-230, Barcelona.

Dedieu, J-P. 1989. L'administration de la foi. L'Inquisition de Tolède, XVIeXVIIIe siècle, Madrid.

Dyonet, N. 1998. «Impietés provinciales au XVIIIe siècle», Histoire, économie et société 9: 391-421.

Eymerich, N. 1982. Manual de Inquisidores, Barcelona.

Gacto, E. 1987. «Un caso de Inquisición. Los carnavales de Tubaria de 1640», en Homenaje al profesor Juan Torres Fontes, Vol. I: 533-546, Universidad de Murcia.

García Cárcel, R. Moreno Martínez, D. 2000. Inquisición. Historia crítica, Barcelona.

García y García, A. 1995. «Los juramentos e imprecaciones en los «Usatges» de Barcelona», Glossae. Revista de historia del derecho europeo 7: 89-123.

Gómez, M.P. 1992. «La ciutat de Lleida contra blasfems, heretges i bruixes», en Miscel.lanea. Homenatge a Josep Lladonosa: 373-394. Lleida.

González Novalín, J.L. 1988. «San Carlos Borromeo y su relación con España», Hispania Sacra 81:193-204.

Graf Von Kalmen. 2002. Juan José de Austria en la España de Carlos II. Historia de una regencia, Lleida.

Gual Vilà, V. 2003. Justicia i terra, La documentació de l'arxiu de Poblet, Vol. I, Valls.

Gual Vilà, V. 2007. Poblet, senyor feudal. La documentació de l'arxiu de Poblet, Vol. II, Valls.

Haliczer, S. 1993. Inquisición y sociedad en el reino de Valencia (14781834), Edicions Alfons el Magnanim, Generalitat Valenciana.

Hillgart, J. N. 1978-1979. «Articuli et monitiones» para los fieles de la diócesis de Barcelona publicadas entre 1420 y 1430», Analecta Sacra Tarraconensia 51-52: 1-6.

Huerga, A. 1988. «La irradiación de San Carlos Borromeo en España a principios del siglo XVII», Hispania Sacra, 81: 179-191.

Kamen, H. 1998. Cambio cultural en la sociedad del Siglo de Oro. Cataluña y Castilla, siglos XVI-XVII, Madrid.

Lalinde Abadía, J. 1966. La jurisdicción real inferior en Cataluña (Corts, Veguer, Batlles), Barcelona. 
Lea, H. 1983. Historia de la Inquisición española, Vol. III, Madrid.

Leveleux, C. 2001. La parole interdite, le blasphème dans la France médiévale (XIIIe-XVIe siècle): du péché au crime, París.

Lladonosa Pujol, E. 1974. Historia de Lleida, Vol. II, Tárrega.

Llompart, G. 1972. «Blasfemias y juramentos cristológicos en la Baja Edad Media catalana», Hispania Sacra XXVII: 137-164.

Martí Bonet, J.M. 1984. Processos de l'Arxiu Diocesà de Barcelona, Col. Cataleg-Inventari d'arxius eclesiàstics de Catalunya, I, Generalitat de Catalunya, Barcelona.

Moliné, E. 1988. «Sinodes d’Urgell del segle XVI», Urgellia 16: 452-460.

Monter, W. 1992. La otra Inquisición, Barcelona.

Moreno Martínez, D. 2002. Representación y realidad de la Inquisición. El conflicto de 1568, (Tesis doctoral), Universitat Autònoma de Barcelona.

Perich Vidal, G. 1989. La Cort del Batlle de Castellar, Castellar del Vallés.

Queipo de Llano, M. T. 1999. «La disciplina del lenguaje blasfemo», en J.L. Pereira. J. M. Gónzalez Beltrán (eds.), V Reunión Científica. Asociación Española de Historia Moderna: 541-548. Universidad de Cádiz.

Redondo, A. 2007. Revisitando las culturas del Siglo de Oro. Mentalidades, tradiciones culturales, creaciones paraliterarias y literarias, Acta Salmanticensia, Estudios filológicos, 314, Universidad de Salamanca.

Romero García, E. 1984. «Procesos criminales en la Lérida de la segunda mitad del siglo XVII», en I Congrés d'Història Moderna de Catalunya, Vol. I: 492-501, Universitat de Barcelona.

Sanahuja, P. 1984. Historia de la ciutat de Balaguer, Balaguer.

Santana Molina, M. 2004. El delito de blasfemia en el tribunal inquisitorial de Cuenca, Universidad de Alicante.

Serra Vilaró, J. 1936. «Ordinacions contra la blasfemia i el joc. Un capitol d'història pirinenca», Analecta Sacra Tarraconensia XII: 412-420.

Serrano Seone, Y. 2006. «El sistema penal del tribunal eclesiástico de la diócesis de Barcelona en la Baja Edad Media», Clio\&Crimen 3: 334-429.

Usunáriz, J. M. 2006. «Verbum Maledictionis. La blasfemia y el blasfemo de los siglos XVI y XVII», en R. García Bourrellier. J. M. Usunáriz (eds.), Aportaciones a la historia social del lenguaje. España, siglos XIV-XVIII: 197-223, Madrid.

Vigarrello, G. 1999. Historia de la violación, XVI-XX, Valencia.

Vinyoles, M. T. 1990. «La violencia marginal a les ciutats medievals (exemples dels volts del 1400)», Revista d'historia medieval, I: 155-177. 